\title{
1 Hydrogen and carbon isotope responses to salinity in greenhouse-cultivated mangroves
}

2 Ji Woon Park ${ }^{\mathrm{a}^{*}}$, S. Nemiah Ladd ${ }^{\mathrm{a}, \mathrm{b}, \mathrm{c}}$, Julian P. Sachs ${ }^{\mathrm{a}}$

$4 \quad{ }^{a}$ University of Washington, School of Oceanography, Seattle, Washington, USA

$5 \quad$ jiwoonp@uw.edu, jsachs@uw.edu

6 bwiss Federal Institute of Aquatic Science and Technology (EAWAG), Department of Surface

7 Waters - Research and Management, Seestrasse 79, 6047 Kastanienbaum, Switzerland

$8 \quad$ Nemiah.Ladd@eawag.ch

$9{ }^{c}$ Swiss Federal Institute of Technology (ETH-Zürich), Department of Earth Sciences,

10 Sonneggstrasse 5, 8092 Zürich, Switzerland

11

$12 *$ Corresponding author: jiwoonp@,uw.edu

This document is the accepted manuscript version of the following article:

Park, J. W., Ladd, S. N., \& Sachs, J. P. (2019). Hydrogen and carbon isotope responses to salinity in greenhouse-cultivated mangroves. Organic Geochemistry, 132, 23-36.

https://doi.org/10.1016/j.orggeochem.2019.03.001 


\section{ABSTRACT}

15 Paired hydrogen and carbon isotope ratios $\left({ }^{2} \mathrm{H} /{ }^{1} \mathrm{H}\right.$ and $\left.{ }^{13} \mathrm{C} /{ }^{12} \mathrm{C}\right)$ of mangrove lipids can be used to

16 quantitatively reconstruct past salinity and ${ }^{2} \mathrm{H} /{ }^{1} \mathrm{H}$ ratios of environmental water, and in some

17 cases precipitation rate. This approach is based on the observation that net ${ }^{2} \mathrm{H}-$ and ${ }^{13} \mathrm{C}$ -

18 fractionation increases and decreases, respectively, with the salinity of environmental water. In

19 order to better understand the mechanisms underlying these empirical observations and

20 ultimately improve estimates of paleoprecipitation from the paired $\mathrm{H}$ and $\mathrm{C}$ isotope approach, we

21 analyzed the isotopic composition of fatty acids from five species of mangroves cultivated in

22 salinity treatments of 5-30 ppt $(\mathrm{g} / \mathrm{kg})$ for 3.5 years in a greenhouse. Decreased net ${ }^{13} \mathrm{C}$ -

23 fractionation with salinity in three mangrove species was attributed to increased water use

24 efficiency and thus a ${ }^{13} \mathrm{C}$-enriched internal $\mathrm{CO}_{2}$ pool. $\mathrm{Net}{ }^{2} \mathrm{H}$-fractionation decreased with

25 salinity in three mangrove species, opposite to previous observations of mangroves growing

26 along salinity gradients in lakes and estuaries. The difference between uncultivated and

27 greenhouse-cultivated mangroves may result from variability of ${ }^{2} \mathrm{H} /{ }^{1} \mathrm{H}$ of environmental water in

28 natural environments. In addition, increased net ${ }^{2} \mathrm{H}$-fractionation with salinity could be due to

29 temporal variability in ${ }^{2} \mathrm{H} /{ }^{1} \mathrm{H}$ of leaf water and timing of lipid production, and the use of stored

30 carbohydrates in seeds. Due to the sensitivity of the salinity and ${ }^{13} \mathrm{C}$-fractionation relationship for

31 calculating both salinity and water isotopes, optimization of mangrove lipid $\mathrm{H}$ and $\mathrm{C}$ isotopes as

32 a paleohydrologic tracer may be best achieved through laboratory-based calibrations of the

33 relationship between ${ }^{13} \mathrm{C}$-fractionation and salinity.

35 Keywords: mangroves, salinity, paleoclimate, hydrogen isotopes, carbon isotopes 


\section{Introduction}

The tropics play an important role in global climate, as tropical convection and ocean-

39 atmosphere interaction affect Earth's radiation budget, global water cycle and precipitation

40 patterns (Pierrehumbert, 2000; Chiang, 2009; Wohl et al., 2012). Current climate model

41 simulations often disagree on future precipitation projections or do not reproduce recent rainfall

42 estimates that agree with observations, and they could be potentially improved with long-term

43 rainfall data from paleo-precipitation proxies (Zhang et al., 2007; Flato et al., 2013; Sun et al.,

44 2017). These proxies include tropical corals, tree rings, ice cores from alpine glaciers and marine

45 sediment cores, but these do not provide high resolution, long-term and continuous records of

46 precipitation in the tropics that span sub-millennial to millennial timescales (Thompson et al.,

47 1985, 2013; Fairbanks et al., 1997; Greer and Swart, 2006; Pfeiffer et al., 2006; Tiwari et al.,

48 2006; Weldeab et al., 2007; Jones et al., 2009; Li et al., 2011).

A promising proxy of past tropical hydroclimate is the hydrogen isotope composition of

50 lipids $\left(\delta^{2} \mathrm{H}=\left(\left({ }^{2} \mathrm{H} /{ }^{1} \mathrm{H}_{\text {sample }}\right) /\left({ }^{2} \mathrm{H} /{ }^{1} \mathrm{H}_{\mathrm{VSMOW}}\right)-1\right)(\% \mathrm{o})\right)$ produced by photoautotrophs and preserved

51 in organic-rich lake and swamp sediments, as such sediment can provide continuous, high-

52 resolution records on millennial timescales. $\delta^{2} \mathrm{H}$ values of cyanobacterial and algal lipids are

53 strongly correlated with $\delta^{2} \mathrm{H}$ values of source environmental water $\left(\delta^{2} \mathrm{H}_{\text {water }}\right)$, both in field- and

54 laboratory-based studies (Sauer et al., 2001; Huang et al., 2004; Englebrecht and Sachs, 2005;

55 Zhang and Sachs, 2007; Maloney et al., 2016, 2019). Similarly, $\delta^{2} H$ values of long-chain $n$ -

56 alkanes and $n$-alkanoic acids produced as leaf waxes by vascular plants are also correlated with

$57 \delta^{2} \mathrm{H}_{\text {precipitation }}$ (Sachse et al., 2004; Polissar and Freeman, 2010; Guenther et al., 2013; Tipple and

58 Pagani, 2013). Because $\delta^{2} \mathrm{H}$ values of environmental water are strongly correlated with

59 precipitation rate over seasonal or longer timescale in the tropics (Dansgaard, 1964; Bony et al., 
60 2008; Risi et al., 2008), $\delta^{2} H_{\text {water }}$ values derived from measurements of $\delta^{2} H_{\text {lipid }}$ of biomarkers from

61 photosynthetic organisms can be used to calculate precipitation rate in the tropics (Smittenberg et

62 al., 2011; Maloney et al., 2019).

63 However, calculating $\delta^{2} \mathrm{H}_{\text {water }}$ values (and ultimately precipitation rates) is complicated

64 by other factors that affect $\delta^{2} \mathrm{H}_{\text {lipid }}$ values. In phytoplankton, $\delta^{2} \mathrm{H}_{\text {lipid }}$ values can be affected by

65 temperature, salinity, light availability, biosynthetic pathway, growth rate, growth phase and

66 source organism (Schouten et al., 2006; Zhang and Sachs, 2007; Zhang et al., 2009; Wolhowe et

67 al., 2009; Nelson and Sachs, 2014; Heinzelmann et al., 2015a, 2015b; Sachs and Kawka, 2015;

68 van der Meer et al., 2015; Sachs et al., 2017; Ladd et al., 2018). Similarly, $\delta^{2} H_{\text {lipid }}$ values of

69 vascular plants (including mangroves) can be affected by temperature, relative humidity, salinity,

70 light intensity, timing of lipid synthesis and evapotranspiration (Smith and Freeman 2006; Yang

71 et al., 2009; Feakins and Sessions 2010; Kahmen et al., 2011a, 2013; Douglas et al., 2012;

72 Sachse et al., 2012; Tipple et al., 2013; Ladd and Sachs, 2015a, 2015b). Despite these

73 complications, several studies have qualitatively reconstructed local precipitation in the tropics

74 by a multi-proxy approach including $\delta^{2} \mathrm{H}_{\text {lipid }}$ values from tropical lake and marine sediments

75 (Schefuß et al., 2005; Pahnke et al., 2007; Tierney et al., 2008; Sachs et al., 2009; Niedermeyer

76 et al., 2010; Smittenberg et al., 2011; Konecky et al., 2013; Atwood and Sachs, 2014; Zhang et

77 al., 2014; Richey and Sachs, 2016; Arnold et al., 2018).

78 The application of leaf wax $\delta^{2} \mathrm{H}_{\text {lipid }}$ values as a precipitation proxy in coastal tropical and

79 subtropical regions can be complicated by the strong influence of salinity on hydrogen isotope

80 fractionation in halophilic plant leaf waxes. About a third of organic matter in tropical and

81 subtropical coastal sediments is produced by leaf litter from mangroves, which are halophilic

82 trees and shrubs that grow widely in the intertidal zones in the tropics and subtropics (Jennerjahn 
83 and Ittekkot, 2002; Giri et al., 2011; Alongi and Mukhopadhyay, 2015). The net fractionation

84 factor for ${ }^{2} \mathrm{H}$ between mangrove leaf lipids and source water (expressed as $\alpha^{2} \mathrm{H}_{\text {lipid-water }}=\left(\delta^{2} \mathrm{H}_{\text {lipid }}\right.$ $\left.85+1000) /\left(\delta^{2} \mathrm{H}_{\text {water }}+1000\right)\right)$ decreases with salinity for alkanes $(0.7-1.8 \%$ ppt $)$ and triterpenoids

$86(0.5-0.9 \%$ ppt) in diverse genera of mangroves (Avicennia, Rhizophora, Bruguiera,

87 Laguncularia) in tropical and subtropical estuaries and lakes from the western Pacific and from

88 Florida (Ladd and Sachs, 2012, 2015a, 2015b, 2017; He et al., 2017). This suggests that if past

89 salinity and water isotopes were to be reconstructed using $\delta^{2} \mathrm{H}_{\text {lipid }}$ values, the salinity effect can

90 be corrected if lipids were specifically derived from mangrove trees. In contrast, using $\delta^{2} \mathrm{H}_{\text {lipid }}$

91 values from generic leaf wax compounds such as long-chain $n$-alkanes may be problematic, since

92 these could come from mixed mangrove/non-mangrove sources and have different responses to

93 changing precipitation rates than mangrove-sourced $n$-alkanes.

94 The pentacyclic triterpenoid taraxerol is particularly useful as a mangrove-specific

95 biomarker, as it is produced in high amounts by Rhizophora spp. mangroves and is well

96 preserved in sediments with minimal diagenetic alteration (Versteegh et al., 2004; Koch et al.,

97 2005). $\delta^{2} \mathrm{H}_{\text {taraxerol }}$ values are influenced by both salinity and $\delta^{2} \mathrm{H}_{\text {water }}$ values, so they cannot be

98 used on their own to estimate precipitation rate, but rather need to be paired with $\delta^{2} \mathrm{H}$ values of

99 algal lipids that grew in the same environment with the mangroves (as in Nelson and Sachs,

100 2016). $\delta^{2} \mathrm{H}$ values of algal lipids are also strongly influenced by salinity, but in the opposite way

101 to that in mangroves, as $\alpha^{2} \mathrm{H}_{\text {lipid-water }}$ in microalgae increases with salinity by $0.7-1.7 \%$ ppt

102 (Schouten et al., 2006; Sachse and Sachs, 2008; Sachs and Schwab, 2011; Chivall et al., 2014;

103 M'boule et al., 2014; Nelson and Sachs, 2014; Heinzelmann et al., 2015a; Maloney et al., 2016;

104 Sachs et al., 2016). Therefore, using the two independent linear relationships between $\alpha^{2} \mathrm{H}_{\text {lipid- }}$ 
water and salinity from both mangrove and algal lipids, salinity and $\delta^{2} \mathrm{H}_{\text {water }}$ can be calculated

106 (Ladd and Sachs, 2012; Nelson and Sachs, 2016).

A second possible approach to estimate salinity and $\delta^{2} \mathrm{H}_{\text {water }}$ is to couple $\delta^{2} \mathrm{H}$ and $\delta^{13} \mathrm{C}$

108 measurements from the same mangrove leaf lipids (Ladd and Sachs, 2013). Since net ${ }^{13} \mathrm{C} /{ }^{12} \mathrm{C}$

109 fractionation between mangrove leaf lipids and atmospheric $\mathrm{CO}_{2}\left(\alpha^{13} \mathrm{C}_{\text {lipid-atm }}\right)$ decreases with

110 salinity by $0.2 \%$ ppt for alkanes in Avicennia marina mangroves, salinity and $\delta^{2} \mathrm{H}$ of

111 environmental water can be calculated from the linear relationships between $\alpha^{2} \mathrm{H}$ or $\alpha^{13} \mathrm{C}$ and

112 salinity (Ladd and Sachs, 2013). This paired $\delta^{2} \mathrm{H} / \delta^{13} \mathrm{C}$ approach can be improved by reducing the

113 uncertainties in the relationship between $\alpha^{13} \mathrm{C}_{\text {lipid-atm }}$ and salinity, as it is less well constrained

114 than the relationship between $\alpha^{2} \mathrm{H}$ and salinity, which has been established across different lipids

115 and mangrove taxa (Ladd and Sachs, 2012, 2015a, 2015b, 2017; He et al., 2017).

116 Another way to improve the accuracy of mangrove lipid-derived salinity and $\delta^{2} \mathrm{H}_{\text {water }}$

117 estimates is to better understand the mechanisms that relate $\alpha^{2} \mathrm{H}_{\text {lipid-water }}$ and $\alpha^{13} \mathrm{C}_{\text {lipid-atm }}$ with

118 salinity. The relationship between $\alpha^{13} \mathrm{C}_{\text {lipid-atm }}$ and salinity has been attributed to higher water use

119 efficiency (WUE) with increasing salinity and increased ${ }^{13} \mathrm{CO}_{2}$ fixation, responses observed in

120 both salt-tolerant and salt-sensitive plants (Farquhar et al., 1982; Brugnoli et al., 1991; Lin and

121 Sternberg, 1992; Sobrado, 2000a; Rivelli et al., 2002; Jiang et al., 2006). The underlying

122 mechanisms accounting for the relationship between $\alpha^{2} \mathrm{H}_{\text {lipid-water }}$ and salinity, however, are less

123 evident. The negative $\alpha^{2} \mathrm{H}-$ salinity relationship has been attributed to variable biosynthetic

124 fractionation between lipids and leaf water (the direct source of hydrogen in lipids from dicots),

125 which may be caused by differences in NADPH sources or reliance on stored carbohydrates, and 126 variable timing of leaf or lipid production (Ladd and Sachs, 2015a, 2015b). However, in the case 127 of B. gymnorhiza growing in marine lakes in Palau, biosynthetic fractionation did not vary with 
128 salinity, suggesting instead that the $\alpha^{2} \mathrm{H}-$ salinity relationship could result from a greater

129 contribution of ${ }^{2} \mathrm{H}$-depleted water vapor to leaf water in a humid climate as salinity increases

130 (Ladd and Sachs, 2017). A better understanding of these mechanisms would facilitate the use of

131 mangrove leaf lipid $\delta^{2} \mathrm{H}$ measurements to reconstruct precipitation rates.

132 To improve the calibration of the relationship between mangrove leaf $\alpha^{13} \mathrm{C}_{\text {lipid-atm }}$ and

133 salinity by reducing uncertainty in the regression statistics, and to assess potential mechanisms

134 causing the inverse relationship between mangrove leaf $\alpha^{2} \mathrm{H}_{\text {lipid-water }}$ and salinity, five species of

135 mangroves that employed different salt management strategies (Table 1) were cultivated in the

136 University of Washington greenhouse for 3.5 years at six different salinity levels $(5,10,15,20$,

$13725,30 \mathrm{ppt}(\mathrm{g} / \mathrm{kg}))$. The $\delta^{2} \mathrm{H}$ and $\delta^{13} \mathrm{C}$ values of leaf wax fatty acids were measured along with the

$138 \delta^{2} \mathrm{H}$ values of growth water and the $\delta^{13} \mathrm{C}$ values of bulk leaves.

140 2. Methods

141 2.1. Cultivation of mangroves in greenhouse

$142 \quad$ 2.1.1. Cultivated species and greenhouse growth conditions

143 We cultivated five species of mangroves (Avicennia germinans, Laguncularia racemosa,

144 Rhizophora apiculata, Rhizophora mangle, and Xylocarpus granatum), each of which relies on

145 different mechanisms to cope with salt stress at six salinity levels $(5,10,15,20,25,30 \mathrm{ppt})$ in

146 the Botany greenhouse at the University of Washington in Seattle. Seeds and propagules of $A$.

147 germinans, L. racemosa and R. mangle were ordered from Florida Plants (Broward Co., FL, 148 USA), while seeds of $R$. apiculata and $X$. granatum were collected during fieldwork on the

149 islands of Pohnpei and Kosrae, Federated States of Micronesia. Seeds (40-50) or propagules

150 from each species were germinated in water with salinity of 5 ppt during September to 
151 November 2012 and then transferred to 1 gallon pots filled with sand in the greenhouse during

152 October to December 2012. All pots were initially supplied with 5 ppt or $10 \mathrm{ppt}$ saltwater, then

153 moved to water with higher salinity after every 4-5 days to help plants adjust to changes in

154 salinity. A water pump pumped and drained water in the tub to a set level above the pots twice

155 every day to simulate a mock tidal cycle. A fertilizer solution $(10 \mathrm{~mL}$ of Peter's Plant Food solid

156 with $1 \mathrm{~L}$ water) was added to all plants weekly. In the greenhouse, temperature ranged between

$157 \quad 15.5^{\circ} \mathrm{C}$ and $23{ }^{\circ} \mathrm{C}$, relative humidity ranged between $25 \%$ and $90 \%$, and light levels between

158 October and April were supplemented by P.L. Light system (600 W). While temperature and

159 relative humidity are expected to be higher in humid tropical climates where these mangrove

160 species grow naturally, field conditions could not be more closely simulated due to other

161 experiments that were conducted in the greenhouse at the same time. Because about half of $R$.

162 apiculata were not growing well, additional $R$. apiculata from Kosrae were added in September

1632013 , and R. apiculata in poor health were removed between November 2013 and January 2014.

164

165 2.1.2. Tub water salinity and $\delta^{2} H$ maintenance

166 Saltwater was produced by adding Instant Ocean Sea Salt to tap water. Salinity was

167 monitored daily with a conductivity probe (Amprobe WT-60), and 2-3 L of tap water was added

168 whenever evaporation caused salinity to increase by $0.5 \mathrm{ppt}$.

169 In January 2013 it was observed that the tub water isotopes had become enriched relative to

170 the starting tap water. To counteract evaporative enrichment, after this point $10 \mathrm{~L}$ of water in

171 each tub was replaced with $10 \mathrm{~L}$ of fresh salt water $\left(\delta^{2} \mathrm{H}=-70 \%\right)$ every week to maintain

172 relatively constant $\delta^{2} \mathrm{H}_{\text {water }}=\sim-50 \%$ over time across all salinity tubs, and tub water samples for

$173 \delta^{2} \mathrm{H}$ measurements were collected weekly before and after water replacement. 


\subsubsection{Harvest}

In order to monitor isotopic variability in leaves over time, one leaf from each $R$. mangle tree was collected and placed into a plastic bag (WhirlPak, Hach, CO, USA) in July 2014 and stored in a freezer at $-20{ }^{\circ} \mathrm{C}$ until further analysis. In March 2016 all trees were completely harvested. For each plant, plant mass above the sand surface, wet root mass and dry root mass was recorded. Leaves were cut off from stem, placed in plastic bags and stored at $-20{ }^{\circ} \mathrm{C}$. Roots were cleaned with water, dried in the oven overnight and stored at $-20{ }^{\circ} \mathrm{C}$.

Development of mangrove seedlings in the greenhouse may have been constrained by temperature and pot size. The temperature range in the greenhouse was lower than that of typical mangrove habitats $\left(20-30^{\circ} \mathrm{C}\right)$, which may have subjected trees to cold stress (Duke, 2006). Limited pot size can also constrain root growth, resulting in reduced photosynthesis and plant biomass (Arp, 1991; Kasai et al., 2012; Poorter et al., 2012). In addition, placing plants inside pots itself can significantly affect root morphology, reducing capability of the roots to take up water efficiently (NeSmith and Duval, 1998).

\subsection{Extraction and purification of lipids from leaves}

For each species, from the group of trees grown in same salinity treatments, two or three trees with healthy-looking leaves were selected. Strips of 2-4 leaves along the midrib from the same tree were freeze-dried and ground together to average out isotopic heterogeneity among leaves or across the base and tip of a single leaf. Total lipid extracts were extracted by Accelerated Solvent Extraction (ASE) following methods previously described by Ladd and Sachs (2015a). The resulting total lipid extract from all species except $R$. mangle was saponified to separate fatty acids and neutral compounds (including alkanes and sterols). Each dry sample was incubated at $70{ }^{\circ} \mathrm{C}$ for $3 \mathrm{~h}$ after adding $3 \mathrm{~mL}$ of $1 \mathrm{~N} \mathrm{KOH} / \mathrm{MeOH}$ and $2 \mathrm{~mL} \mathrm{HPLC}$-grade 
$\mathrm{H}_{2} \mathrm{O}$ and cooled to room temperature. Hexane $(2 \mathrm{~mL})$ was added to the saponified samples and

200 vortexed, and the organic phase (containing neutral compounds) was transferred to new vials.

201 After 4-5 hexane rinses, 15-20 drops of 4N HCl was added to the saponified samples to

202 decrease the $\mathrm{pH}$ below 2 . Then, $2 \mathrm{~mL}$ of hexane was added $4-5$ times to the acidic saponified

203 samples and vortexed, and the organic phase (containing protonated fatty acids) was transferred

204 to new vials. For $R$. mangle, in order to separate alkanes and triterpenoids from other types of

205 neutral compounds, the lipid extracts were purified using column chromatography methods

206 previously described by Ladd and Sachs (2015a).

207 A $2 \%$ aliquot of fatty acids and alcohols from all species was silylated by adding $20 \mu \mathrm{L}$

208 pyridine and $20 \mu \mathrm{L}$ BSTFA at $60{ }^{\circ} \mathrm{C}$ for $1 \mathrm{~h}$. Lipid composition was identified by gas

209 chromatography-mass spectrometry (GC-MS) with an Agilent (Santa Clara, CA, USA) 6890N

210 gas chromatograph with an Agilent 5975 quadrupole mass selective detector and an Agilent DB-

2115 column $(60 \mathrm{~m} \times 0.25 \mathrm{~mm} \times 0.25 \mu \mathrm{m})$ with helium as the carrier gas $(1.1 \mathrm{~mL} / \mathrm{min}$ flow $)$. The

$212 \mathrm{GC}$ was heated initially to $100{ }^{\circ} \mathrm{C}$ for $2.1 \mathrm{~min}$, then at $5^{\circ} \mathrm{C} / \mathrm{min}$ to $320^{\circ} \mathrm{C}$ for $23.9 \mathrm{~min}$.

213 Compounds were identified based on retention times and comparisons with published mass

214 spectra.

215 Half of the remaining $98 \%$ of the acid fraction was methylated with the methylating agent

216 prepared by adding $5 \mathrm{~mL}$ of acetyl chloride to $50 \mathrm{~mL}$ of anhydrous methanol chilled in an ice

217 bath. Dry hexane (1 mL) and $2 \mathrm{~mL}$ of methylating agent was added to each sample, vortex-

218 mixed and heated in an oven at $60{ }^{\circ} \mathrm{C}$ for $24 \mathrm{~h}$. After cooling samples to room temperature, $2 \mathrm{~mL}$

219 of HPLC-grade $\mathrm{H}_{2} \mathrm{O}$ and $2 \mathrm{~mL}$ of hexane were added, vortex-mixed and separated three times.

220 Half of the remaining $98 \%$ of the sterol fraction from $R$. mangle leaves was acetylated by adding

$22120 \mu \mathrm{L}$ pyridine and $20 \mu \mathrm{L}$ acetic anhydride with known $\delta^{2} \mathrm{H}$ composition at $70{ }^{\circ} \mathrm{C}$ for 30 mins. 5 
$222 \alpha$-cholestane was added as a quantification standard to $25-75 \%$ aliquots of methylated samples.

223 The samples were quantified on an Agilent 6890N gas chromatograph (GC) with flame

224 ionization detector (GC-FID) and an Agilent VF-17ms column $(60 \mathrm{~m} \times 0.25 \mathrm{~mm} \times 0.25 \mu \mathrm{m})$

225 with helium $(1.4 \mathrm{~mL} / \mathrm{min})$ as the carrier gas. The $\mathrm{GC}$ was heated initially to $100{ }^{\circ} \mathrm{C}$ for $2.1 \mathrm{~min}$,

226 then at $5{ }^{\circ} \mathrm{C} / \mathrm{min}$ to $320^{\circ} \mathrm{C}$ where it was held for $23.9 \mathrm{~min}$.

227 The saponification, isolation, and derivatization of fatty acids as described does not result in 228 detectable isotope fractionation (Zhang and Sachs, 2007; Smittenberg et al., 2011; Sachs and 229 Kawka, 2015; Maloney et al., 2016; Sachs et al., 2017, 2018).

$231 \quad 2.3 . \quad$ Lipid $\delta^{2} H$ and $\delta^{13} C$ analysis

232 Fatty acid samples from all five mangrove species were diluted with toluene to a

233 concentration of $\sim 150 \mathrm{ng} / \mu \mathrm{L}$ (for $\delta^{2} \mathrm{H}$ analyses) or $\sim 40 \mathrm{ng} / \mu \mathrm{L}$ (for $\delta^{13} \mathrm{C}$ analyses) prior to

234 measurement by gas chromatography-isotope ratio mass spectrometry (GC-IRMS) at the

235 University of Washington on equipment described previously (Ladd and Sachs, 2015a). For fatty

236 acid analysis, an Agilent DB-5ms column $(60 \mathrm{~m} \times 0.25 \mathrm{~mm} \times 0.25 \mu \mathrm{m})$ was used, with helium as

237 the carrier gas $(1.5 \mathrm{~mL} / \mathrm{min}$ flow $)$. The $\mathrm{GC}$ was initially heated to $120^{\circ} \mathrm{C}$, then at $20^{\circ} \mathrm{C} / \mathrm{min}$ to

$238180{ }^{\circ} \mathrm{C}$, then at $3{ }^{\circ} \mathrm{C} / \mathrm{min}$ to $325^{\circ} \mathrm{C}$ and held for $16 \mathrm{~min}$. Alkanes and triterpenols from R. mangle

239 were diluted to the same concentrations, and analyzed using an Agilent VF-17ms column (60 m

$240 \times 0.25 \mathrm{~mm} \times 0.25 \mu \mathrm{m})$, also with helium as the carrier gas $(1.1 \mathrm{~mL} / \mathrm{min}$ flow $)$. The GC was

241 initially heated to $120^{\circ} \mathrm{C}$, then at $20^{\circ} \mathrm{C} / \min$ to $260^{\circ} \mathrm{C}$, then at $1{ }^{\circ} \mathrm{C} / \mathrm{min}$ to $300^{\circ} \mathrm{C}$, and then at

$24220^{\circ} \mathrm{C} / \mathrm{min}$ to $325^{\circ} \mathrm{C}$ and held for $18.5 \mathrm{~min}$. Each sample was injected three times for each

243 isotope measurement. 
Performance of the instrument was evaluated by running a mix of external standards $\left(\mathrm{C}_{21}\right.$,

$245 \mathrm{C}_{23}, \mathrm{C}_{28}, \mathrm{C}_{32}, \mathrm{C}_{34}, \mathrm{C}_{38} n$-alkanes) after every 4 or 5 samples and co-injecting a mix of internal

246 standards $\left(\mathrm{C}_{26}, \mathrm{C}_{32}, \mathrm{C}_{38} n\right.$-alkanes $)$ with each sample. All $n$-alkane isotopic reference standards

247 and their $\delta^{2} \mathrm{H}$ and $\delta^{13} \mathrm{C}$ values were provided by A. Schimmelmann, University of Indiana. The

248 average standard deviations of the external standards were $2.8 \%$ for $\delta^{2} \mathrm{H}$ analyses and $0.26 \%$ for

$249 \quad \delta^{13} \mathrm{C}$ analyses.

$250 \quad$ Raw $\delta^{2} \mathrm{H}$ and $\delta^{13} \mathrm{C}$ values from the instrument were corrected using Thermo ISODAT

251 software V. 2.5 as described previously (Ladd and Sachs, 2015a). Fatty acid $\delta^{2} \mathrm{H}$ and $\delta^{13} \mathrm{C}$ were

252 corrected for methylation using a phthalic acid standard with known $\delta^{2} \mathrm{H}=-95.5 \pm 2.2 \%$ and

$253 \delta \delta^{13} \mathrm{C}=-27.21 \pm 0.02 \%$ (data from A. Schimmelmann) that was methylated and measured in the

254 same way as the fatty acid samples. The $\mathrm{H}_{3}{ }^{+}$factor was determined at the start of each sequence,

255 using pulses of a reference gas of varying heights, and was $1.66 \pm 0.07$ during November 2016

256 and March 2017 when A. germinans, L. racemosa, R. apiculata and R. mangle samples were

257 analyzed, and 2.04 when X. granatum samples were analyzed in February 2018.

$258 \delta^{2} \mathrm{H}$ values of triterpenols in leaves from 2014 and 2016 in each salinity treatment were

259 averaged to calculate $\alpha^{2} \mathrm{H}_{2016-2014}=\left(\delta^{2} \mathrm{H}_{2016}+1000\right) /\left(\delta^{2} \mathrm{H}_{2014}+1000\right)$ in each salinity at each

260 time, and fractionation factors between R. mangle lipids harvested in 2014 and 2016 were

261 calculated with the equation $\varepsilon_{2016-2014}=\left(\alpha^{2} \mathrm{H}_{2016-2014}-1\right) \times 1000(\%)$ (Supplementary Table

262 S3). 


\subsection{Source water $\delta^{2} H$ analysis}

$265 \quad \delta^{2} \mathrm{H}$ values of tub water samples $\left(\delta^{2} \mathrm{H}_{\text {water }}\right)$ collected between July 2014 and March 2016 were

266 measured by Cavity Ring Down Spectroscopy following the methods described by Ladd and

267 Sachs (2015a), and the average precision of the final three injections was $0.33 \%$ for $\delta^{2} \mathrm{H}$.

268 Fractionation factors of ${ }^{2} \mathrm{H}$ between lipids and environmental water $\left(\alpha^{2} \mathrm{H}_{\text {lipid-water }}\right)$ at harvest

269 were calculated using the last two measured $\delta^{2} \mathrm{H}_{\text {water }}$ values (from February and March, 2016) in

270 order to represent as closely as possible the isotopic composition of water used to synthesize the

271 leaf lipids, since fatty acids in plant leaf waxes are recycled every few days (Gao et al., 2012)

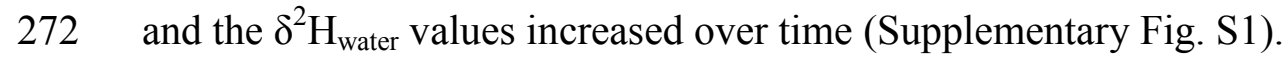

274 2.5. Bulk leaf $\delta^{13}$ C analysis

275 Leaves (1-3) from the same trees selected for lipid $\delta^{13} \mathrm{C}$ analysis were dried in the oven at 60

$276{ }^{\circ} \mathrm{C}$ for $24 \mathrm{~h}$, taken out and left outside for $24 \mathrm{~h}$ to prevent over-drying and ground homogenously.

277 About $4 \mathrm{mg}$ of each leaf powder was enclosed in tin capsules and sent to the UC Davis Stable

278 Isotope Facility for bulk leaf $\delta^{13} \mathrm{C}$ analysis on a PDZ Europa ANCA-GSL elemental analyzer

279 connected to a PDZ Europa 20-20 isotope ratio mass spectrometer (Sercon Ltd., Cheshire, UK).

280 The samples were combusted in an oxidation reactor filled with chromium oxide and silver

281 copper oxide at $1000{ }^{\circ} \mathrm{C}$ with helium flow, producing $\mathrm{N}_{2}, \mathrm{CO}_{2}$, water and oxides. To remove

282 water and oxides these products went through a reduced copper reactor and a magnesium

283 perchlorate water trap. $\mathrm{CO}_{2}$ and $\mathrm{N}_{2}$ were separated on a Carbosieve $\mathrm{GC}$ column $\left(65^{\circ} \mathrm{C}, 65\right.$

$284 \mathrm{~mL} / \mathrm{min}$ ) before entering the IRMS for isotope analysis. 
$\delta^{2} \mathrm{H}$ values of leaf water $\left(\delta^{2} \mathrm{H}_{\mathrm{lw}}\right)$ were calculated using a Péclet-modified Craig Gordon model from Kahmen et al. (2011b), as described previously by Ladd and Sachs (2015b, 2017).

289 The modeled $\delta^{2} \mathrm{H}_{\mathrm{lw}}$ values were used to compare the effect of salinity on $\delta^{2} \mathrm{H}_{\mathrm{lw}}$ in the greenhouse 290 and to evaluate if the influence of salinity on $\delta^{2} \mathrm{H}_{\text {lw }}$ can account for differences in $\delta^{2} \mathrm{H}_{\text {lipid }}$ across a

291 salinity gradient. Initially, a sensitivity test was performed with the leaf water model by 292 calculating the range of $\delta^{2} \mathrm{H}_{\mathrm{lw}}$ values from end-member values of one variable at a time while 293 holding the other variables constant. The range of temperature and relative humidity is as 294 described in Section 2.1.1., and the range of $\delta^{2} \mathrm{H}_{\text {atmospheric vapor was determined from }}$ 295 measurements with an isotopic water vapor analyzer (Los Gatos Research, San Jose, CA) during 2962013 January.

297 The range of stomatal conductance $\left(\mathrm{g}_{\mathrm{s}}\right)\left(\right.$ rate of water vapor loss, $\mathrm{mol} / \mathrm{m}^{2} / \mathrm{s}$ ) encompasses 298 published observations from A. germinans, L. racemosa and R. mangle leaves (Lin and 299 Sternberg, 1992; Sobrado 2000a, 2000b; Krauss and Allen, 2003; Biber 2006). The range of 300 effective path length $(\mathrm{L}, \mathrm{mm})$ was derived from published values in several species of mangroves 301 (Ellsworth et al., 2013; Liang et al., 2018). The range of $\delta^{2} \mathrm{H}$ values of xylem water $\left(\delta^{2} \mathrm{H}_{\mathrm{xw}}\right)$ was 302 calculated using published $\alpha_{\mathrm{xw}-\mathrm{sw}}$ values (Ladd and Sachs, 2015b) and measured $\delta^{2} \mathrm{H}_{\text {water }}$ values, 303 and accounts for the fractionation due to discrimination against ${ }^{2} \mathrm{H}$ at roots during water uptake 304 that has been observed in mangroves (Lin and Sternberg, 1993). As $\delta^{2} H_{\text {water }}$ values in the 305 greenhouse were relatively stable (Supplementary Fig. S1), and $\alpha_{\mathrm{xw}-\mathrm{sw}}$ decreases at high salinity 306 (Lin and Sternberg, 1993; Ladd and Sachs, 2015b), $\delta^{2} \mathrm{H}_{\mathrm{xw}}$ values are expected to be ${ }^{2} \mathrm{H}$-depleted 307 at high salinity in our case. 
Among the variables included in the model, stomatal conductance, $\delta^{2} \mathrm{H}_{\mathrm{xylem}}$ water and effective

309 path length were identified to vary directly with salinity. We assessed the variation in $\delta^{2} \mathrm{H}_{1 \mathrm{w}}$

310 values from changes in these three factors across the 25 ppt salinity range, but did not account

311 for species-specific differences in the factors, as the results of our sensitivity test suggested that

312 the effects of species-specific variations in these variables are not as significant as effects from

313 other variables common across species (Table 2, Supplementary Table S1). In our final

314 calculations, $\mathrm{g}_{\mathrm{s}}$ of $R$. mangle from Lin and Sternberg (1992) $\left(0.35 \mathrm{~mol} / \mathrm{m}^{2} / \mathrm{s}\right.$ at $5 \mathrm{ppt}$ and 0.15

$315 \mathrm{~mol} / \mathrm{m}^{2} / \mathrm{s}$ at $30 \mathrm{ppt}$ ) was used. L at 5 and $30 \mathrm{ppt}$ were estimated using the inverse relationship

316 between L and transpiration rate (Song et al., 2013), where the transpiration rate at each salinity

317 was calculated from the $\mathrm{g}_{\mathrm{s}}$ values above. $\delta^{2} \mathrm{H}_{\mathrm{lw}}$ values at $5 \mathrm{ppt}$ and $30 \mathrm{ppt}$ were calculated with

318 the leaf water model using end-members of these three variables while keeping other variables

319 constant (Table 3).

320 In addition, to assess the diurnal isotopic variability of leaf water, different "daytime" and

321 "nighttime" temperature, relative humidity and atmospheric vapor $\delta^{2} \mathrm{H}$ values (Table 4) were

322 used to calculate daytime and nighttime $\delta^{2} \mathrm{H}_{1 \mathrm{w}}$ values. A daytime temperature of $21{ }^{\circ} \mathrm{C}$ and a

323 nighttime temperature of $17^{\circ} \mathrm{C}$ were employed for this calculation. Relative humidity was

324 estimated using water vapor content and saturated vapor pressure calculated from temperature.

325 An estimate of uncertainty for modeled $\delta^{2} \mathrm{H}_{1 \mathrm{w}}$ values was derived from a Monte Carlo

326 approach with 1000 iterations that included the uncertainties for all model variables.

\section{2.7. Statistical analysis}

329 Simple ordinary least square regression was used to calculate the correlations between $\delta^{2} \mathrm{H}$, $330 \delta^{13} \mathrm{C}$ or $\alpha^{2} \mathrm{H}_{\text {lipid-water }}$ and salinity. In addition, to account for different magnitude of standard errors 
331 in the triplicate $\delta^{2} \mathrm{H}$ and $\delta^{13} \mathrm{C}$ measurements, using a dummy data point $\left(\delta^{2} \mathrm{H}=-100 \pm 5 \%, \delta^{13} \mathrm{C}\right.$ $332=-30 \pm 0.3 \%$ ), a 1000 iteration Monte Carlo analysis with normally distributed errors from $\delta^{2} \mathrm{H}$ 333 and $\delta^{13} \mathrm{C}$ standard errors was conducted to calculate slopes, intercepts and associated

334 uncertainties.

\section{3. Results}

337 3.1. Relationship between salinity and $\delta^{13} C_{\text {fatty acid }}$

338 Out of five species, three (L. racemosa, R. apiculata and X. granatum) had significant ( $\mathrm{p}<$ $3390.05)$ positive correlations between salinity and $\delta^{13} \mathrm{C}_{\text {fatty acid }}\left(\mathrm{R}^{2}=0.51\right.$ for L. racemosa $n-\mathrm{C}_{18}$, 3400.45 for $R$. apiculata $n-\mathrm{C}_{16}, 0.69$ for $R$. apiculata $n-\mathrm{C}_{18}, 0.35$ for $X$. granatum $n-\mathrm{C}_{16}$ and 0.36 for $341 X$. granatum $n-\mathrm{C}_{18}$ ) (Fig. 1; Table 5). Slopes of the relationship between salinity and $\delta^{13} \mathrm{C}_{\text {fatty acid }}$ 342 calculated from ordinary least square regression were similar in L. racemosa and R. apiculata $343\left(0.123 \pm 0.008\right.$ for $R$. apiculata $n-\mathrm{C}_{16}, 0.207 \pm 0.009$ for $R$. apiculata $n-\mathrm{C}_{18}, 0.207 \pm 0.009$ for $L$. 344 racemosa $n$ - $\left.\mathrm{C}_{18}\right)$, while slopes from $X$. granatum were about half as steep $(0.086 \pm 0.006$ for $n$ $345 \mathrm{C}_{16}, 0.095 \pm 0.009$ for $n$ - $\left.\mathrm{C}_{18}\right)$. Fatty acids from $X$. granatum $(-38.1 \pm 1.4 \%$ ) were more depleted 346 than fatty acids from L. racemosa and R. apiculata (each $-34.1 \pm 2.3 \%$ and $-33.3 \pm 1.9 \%$ )

347 (Supplementary Table S2). In contrast, the other two species (A. germinans and R. mangle) did 348 not have significant relationships between salinity and $\delta^{13} \mathrm{C}_{\text {fatty acid. }}$.

$350 \quad 3.2$. Relationship between salinity and $\delta^{13} C_{\text {bulk leaf }}$

351 A significant positive correlation $(\mathrm{p}<0.05)$ between salinity and $\delta^{13} \mathrm{C}_{\text {bulk leaf }}$ was observed in 352 L. racemosa $\left(\mathrm{R}^{2}=0.90\right)$, R. apiculata $\left(\mathrm{R}^{2}=0.74\right)$ and $X$. granatum $\left(\mathrm{R}^{2}=0.56\right)($ Fig. 2 ; Table 6). 353 Slopes of the relationship calculated from ordinary least square regression were of a similar order 
354 to the slopes of salinity vs $\delta^{13} \mathrm{C}_{\text {fatty acid }}(0.164 \pm 0.020$ for L. racemosa, $0.220 \pm 0.034$ for $R$.

355 apiculata and $0.101 \pm 0.021$ for X. granatum). R. mangle showed a significant negative

356 correlation between salinity and $\delta^{13} \mathrm{C}_{\text {bulk leaf }}\left(\mathrm{p}=0.032, \mathrm{R}^{2}=0.26, \mathrm{~m}=-0.070 \pm 0.030\right)$, while $A$.

357 germinans did not show a significant correlation $(\mathrm{p}=0.555)$.

359 3.3. Relationship between salinity and $\delta^{2} H_{\text {fatty acid }}$

360 Three of the five species (R. apiculata, R. mangle and X. granatum) displayed significant ( $\mathrm{p}$

$361<0.05)$ correlations between salinity and $\delta^{2} \mathrm{H}_{\text {fatty acid }}\left(\right.$ Fig. 3; Table 5). In all three, $\delta^{2} \mathrm{H}_{\text {fatty acid }}$

362 values were positively correlated with salinity $\left(\mathrm{R}^{2}=0.48\right.$ for $R$. apiculata $n-\mathrm{C}_{16}, 0.31$ for $R$.

363 apiculata $n-\mathrm{C}_{18}, 0.39$ for $R$. mangle $n-\mathrm{C}_{16}$ and 0.22 for $X$. granatum $n-\mathrm{C}_{18}$ ). The slopes of the

364 relationships between salinity and $\delta^{2} \mathrm{H}_{\text {fatty acid }}$ calculated from ordinary least square regression

365 were greater in R. apiculata $\left(1.253 \pm 0.113\right.$ and $1.179 \pm 0.113$ each for $n-\mathrm{C}_{16}$ and $n-\mathrm{C}_{18}$ fatty

366 acids) than in either $R$. mangle $\left(0.474 \pm 0.142\right.$ for $n-\mathrm{C}_{16}$ fatty acid $)$ or $X$. granatum $(0.529 \pm 0.060$

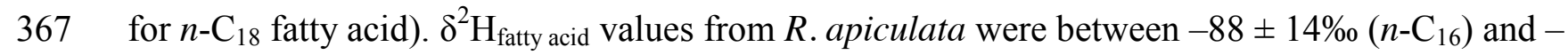

$36874 \pm 16 \%$ o $\left(n-\mathrm{C}_{18}\right)$, which were generally more depleted than fatty acids from $R$. mangle $(-81 \pm$

$3697 \%$ for $\left.n-\mathrm{C}_{16}\right)$ or from $X$. granatum $\left(-85 \pm 7 \%\right.$ for $\left.n-\mathrm{C}_{18}\right)$ (Supplementary Table S2).

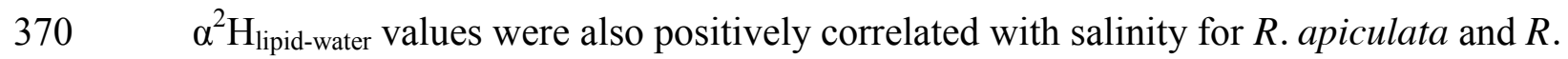

371 mangle $\left(\mathrm{R}^{2}=0.48\right.$ for $R$. apiculata $n-\mathrm{C}_{16}, 0.31$ for $R$. apiculata $n-\mathrm{C}_{18}$, and 0.36 for $R$. mangle $n$ -

$\left.372 \mathrm{C}_{16}\right)$, but the correlation was not significant in X. granatum $(\mathrm{p}=0.105)$ (Fig. 4; Table 5). Lipids

373 from the other two species (A.germinans and L. racemosa) did not display significant

374 relationships between either $\delta^{2} \mathrm{H}_{\text {fatty acid }}$ and salinity or $\alpha^{2} \mathrm{H}_{\text {lipid-water }}$ and salinity. 


\subsection{Leaf water model results}

377 Results of the sensitivity test show that modeled $\delta^{2} \mathrm{H}_{\mathrm{lw}}$ values are more sensitive to changes

378 in $\delta^{2} \mathrm{H}_{\text {vapor }}$ values, relative humidity and temperature, than they are to changes in stomatal

379 conductance and effective path length (Table 2).

380 As salinity increased from $5 \mathrm{ppt}$ to $30 \mathrm{ppt}$, stomatal conductance was estimated to decrease

381 from $0.35 \mathrm{~mol} / \mathrm{m}^{2} / \mathrm{s}$ to $0.15 \mathrm{~mol} / \mathrm{m}^{2} / \mathrm{s}$ (Lin and Sternberg, 1992), $\delta^{2} \mathrm{H}_{\mathrm{xw}}$ values were estimated to

382 be ${ }^{2} \mathrm{H}$-depleted by $7.6 \%$, and path length was estimated to increase from $120 \mathrm{~mm}$ to $280 \mathrm{~mm}$.

383 These variables ultimately resulted in modeled $\delta^{2} \mathrm{H}_{\mathrm{lw}}$ values that are depleted by $2.7 \% 0$ at $30 \mathrm{ppt}$

384 relative to $5 \mathrm{ppt}$ (Table 3$). \delta^{2} \mathrm{H}_{\mathrm{lw}}$ values were more depleted under daytime conditions $(-42.2 \pm$

$3853.4 \%$ ) than under nighttime conditions $(-25.9 \pm 2.8 \%)$.

$387 \quad 3.5 . \quad \delta^{2} H_{\text {triterpenoids }}$ in $R$. mangle leaves harvested in 2014 and 2016

$388 \quad \delta^{2} \mathrm{H}$ values of three triterpenoids (taraxerol, $\beta$-amyrin and lupeol) were more ${ }^{2} \mathrm{H}$-depleted in 3892016 than in 2014 in 15 of 18 R. mangle treatments (Fig. 5; Supplementary Table S2). There

390 were no statistically significant relationships (at $\mathrm{p}<0.05$ ) between salinity and $\delta^{2} \mathrm{H}_{\text {triterpenoids }}$ of $R$.

391 mangle harvested in either year, or between salinity and $\varepsilon_{2016-2014}$ for any of the three

392 triterpenoids (Supplementary Table S1).

393

\section{4. Discussion}

395 4.1. Relationships between salinity and $\delta^{13} C_{\text {fatty acid }}$ of cultivated mangroves

396 4.1.1. Effect of water use efficiency on $\delta^{13} C_{\text {fatty acid }}$ and $\delta^{13} C_{\text {bulk leaf }}$

397 The significant positive correlation between $\delta^{13} \mathrm{C}_{\text {bulk leaf }}$ values and salinity of cultivated $L$.

398 racemosa, $R$. apiculata and X. granatum observed in this study (Table 6) is consistent with past 
studies (Farquhar et al., 1982; Sobrado, 2000a; Ladd and Sachs, 2013). This has been attributed

400 to increased WUE at high salinity, which results in limited exchange of $\mathrm{CO}_{2}$ between the

401 atmosphere and the intercellular air space under high salinity treatments and more incorporation

402 of ${ }^{13} \mathrm{C}$ into leaf lipids from a ${ }^{13} \mathrm{C}$-enriched internal $\mathrm{CO}_{2}$ pool (Farquhar et al., 1982, 1989).

403 Generally, the observed correlation between $\delta^{13} \mathrm{C}_{\text {bulk leaf }}$ and salinity $\left(\mathrm{R}^{2}\right.$ range $\left.0.56-0.90\right)$ is

404 stronger than that between $\delta^{13} \mathrm{C}_{\text {fatty acid }}$ and salinity $\left(\mathrm{R}^{2}\right.$ range $\left.0.35-0.69\right)$ (Tables 5 and 6). The

405 correlation between $\delta^{13} \mathrm{C}_{\text {bulk leaf }}$ and salinity in greenhouse-cultivated trees is also much higher

406 than that in uncultivated trees (Ladd and Sachs, 2013). This strong relationship may have

407 resulted from the nitrogen fertilizer we supplied to the greenhouse-cultivated mangroves. Martin

408 et al. (2010) observed that N-fertilized A. marina have higher WUE than trees without fertilizer,

409 possibly because the additional nitrogen was allocated to Rubisco to keep up with high carbon

410 assimilation rates. Since the greenhouse-cultivated trees were supplied with nitrogen fertilizers

411 throughout their growth, it may be possible that greenhouse-cultivated trees had higher WUE and

412 reduced intercellular $\mathrm{CO}_{2}$ concentration relative to uncultivated trees, resulting in a relatively

413 strong positive trend between salinity and $\delta^{13} \mathrm{C}_{\text {bulk leaf }}$ values.

414 There were no significant correlations between salinity and $\delta^{13} \mathrm{C}_{\text {fatty acid }}$ or $\delta^{13} \mathrm{C}_{\text {bulk leaf }}$ in $A$.

415 germinans and $R$. mangle. These two species are highly salt-tolerant, and maintain high WUE

416 across wide ranges of salinity (Reef and Lovelock, 2015). If these species can lower water

417 potential by efficiently secreting through salt glands (A. germinans) or accumulating solutes in

418 cytoplasm (A.germinans and R. mangle) (Table 1), they may rely relatively less on stomatal

419 opening and closure to minimize water loss. However, while mangrove species with salt glands

420 (Aegiceras corniculatum, Aegialitis annulata, A. marina) have been observed to lack

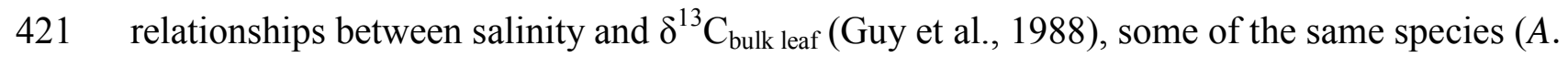


422 corniculatum and A. marina) have also been observed to have lower stomatal conductance and

423 carbon assimilation rate with increasing salinity, despite high solute concentrations in their

424 leaves (Ball and Farquhar, 1983). Therefore, while the lack of correlation between salinity and

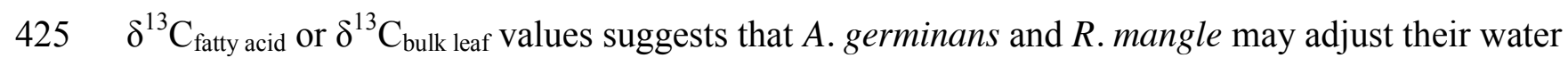

426 potentials by excluding excess salt rather than limiting water loss through the stomata, additional

427 studies are required to establish the significance of these salt exclusion strategies in maintaining

428 high WUE.

429

430 4.1.2. Plant growth correlated with salinity and $\delta^{13} C_{\text {fatty acid }}$

431 Dry root mass and wet plant mass are good measures of halophilic plant growth. With

432 increasing salinity, halophilic plants increase root mass to obtain water, reinforce cell-wall

433 lignification to limit salt absorption (Cheng et al., 2012; Vovides et al., 2014), and decrease

434 stomatal conductance and carbon assimilation rates (Ball and Farquhar, 1983); therefore, plants

435 under high salt stress are expected to have higher dry root mass and lower wet plant mass. In our

436 study, L. racemosa and X. granatum displayed a decrease in total wet mass as salinity increased

437 (Supplementary Fig. S2), implying that growth was suppressed at high salinity. This observation

438 is consistent with the suggestion above that these species decrease their stomatal conductance to

439 increase WUE, and further supports the explanation that WUE is primarily responsible for the

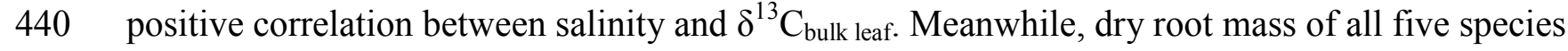

441 decreased or did not change significantly with increasing salinity (Supplementary Fig. S3),

442 which may suggest that factors other than salinity, such as lower temperature and relative

443 humidity or limited pot size, may have had larger influences on the growth of greenhouse-

444 cultivated mangroves. However, as environmental factors in the greenhouse other than salinity 
445 were equally imposed on all plants, carbon isotope fractionation observed in fatty acids and bulk

446 lipids in greenhouse-cultivated mangroves is likely controlled by increased WUE in response to

447 salinity.

$448 \quad$ Nevertheless, given that the positive correlations between $\delta^{13} \mathrm{C}_{\text {lipid }}$ and salinity in three

449 different species of cultivated mangroves (L. racemosa, R. apiculata and X. granatum) were

450 similar to that in the field (Ladd and Sachs, 2013), incorporating a larger set of greenhouse-

451 cultivated and uncultivated samples may help to decrease uncertainty in the relationship between

$452 \quad \alpha^{13} \mathrm{C}$ and salinity for some mangrove species.

453

454 4.2. Relationships between salinity and $\delta^{2} H_{\text {fatty acid }}$ of greenhouse mangroves

455 4.2.1. Differing trends among cultivated and uncultivated mangroves

456 Field studies have documented negative correlations between salinity and $\alpha^{2} \mathrm{H}_{\text {lipid-water }}$ of

457 various lipids (including $n-\mathrm{C}_{29}$ and $n-\mathrm{C}_{31}$ alkanes, taraxerol, stigmasterol, and sitosterol) from

458 different mangrove species in diverse settings, including lakes and estuaries in Australia, Palau,

459 Micronesia, and Florida (Ladd and Sachs, 2012, 2015a, 2015b, 2017; He et al., 2017). These

460 published results differ from the positive correlations observed in greenhouse-cultivated $R$.

461 apiculata and R. mangle in this study (Fig. 4; Table 5). The discrepancy may be due to

462 differences in environmental parameters between the field and the greenhouse, such as $\delta^{2} \mathrm{H}_{\text {water, }}$,

463 or to different responses of individual lipid compounds to salinity (Ladd and Sachs, 2012, 2015a,

464 2015b, 2017; He et al., 2017).

465 A major difference between field and greenhouse settings is that there are alternate fresh or

466 less-saline water sources that may be utilized by trees in the field. Several studies have proposed

467 that mangroves opportunistically take up fresh or less-saline water through their roots during 
precipitation events (Lambs et al., 2008; Wei et al., 2013; Santini et al., 2015) or from

469 groundwater (Ewe et al., 2007; Sternberg and Swart, 1987), or through their leaves when wetted

470 by rain or dew (Reef and Lovelock, 2015; Steppe et al., 2018). Hydrogen and oxygen isotope

471 mixing models have been used to determine quantitative contributions of different water sources,

472 such as soil water, groundwater, and rainwater. Studies estimated that scrub A. marina use 37-93

$473 \%$ rainwater, $R$. stylosa use $21-41 \%$ groundwater and $14-20 \%$ dew and L. racemosa use $24 \%$

474 groundwater and 9\% dew (Wei et al., 2013; Lovelock et al., 2017). Since freshwater is more

475 depleted in ${ }^{2} \mathrm{H}$ than seawater, field trees under high salt stress may have been more dependent on

476 opportunistic freshwater uptake than trees under low salt stress, resulting in the production of

477 lipids that are more ${ }^{2} \mathrm{H}$-depleted relative to the surface water from which net $\alpha^{2} \mathrm{H}_{\text {lipid-water }}$ values

478 are calculated (Ladd and Sachs, 2017). Unlike in the field, where rain, dew, and low-salinity

479 water sources may be at least sporadically available to mangroves, in the greenhouse, $\delta^{2} \mathrm{H}_{\text {water }}$

480 was held relatively constant across the $25 \mathrm{ppt}$ salinity range. Supplementary Fig. S1 shows that

481 while growth water became slightly more ${ }^{2} \mathrm{H}$-enriched over $\sim 1.5$ years, differences in $\delta^{2} \mathrm{H}_{\text {water }}$

482 across salinities were about $8 \%$, which is small relative to the observed differences between $\delta^{2} \mathrm{H}$

483 of freshwater and saline water in the field (about 30\%o) (Ladd and Sachs, 2015b). Therefore, the

484 lack of strong positive correlation between $\alpha^{2} \mathrm{H}_{\text {lipid-water }}$ and salinity in greenhouse-cultivated trees

485 may be due to the fact that, unlike trees in the field, they had no access to water with different

$486 \delta^{2} \mathrm{H}$ values than that provided in the growth tubs. In addition, while the field studies (Ladd and

487 Sachs, 2012, 2015b, 2017) found that the correlation coefficient between salinity and $\alpha^{2} \mathrm{H}_{\text {lipid-water }}$

488 was higher than that between salinity and $\delta^{2} \mathrm{H}_{\text {lipid, }}$ our results show that the strength of the two

489 correlations are about the same, or even lower in the case of $X$.granatum. The strong

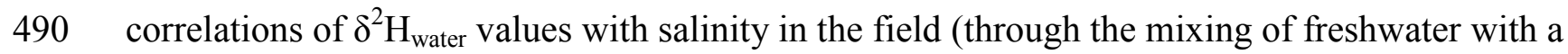


491 low $\delta^{2} \mathrm{H}$ value and seawater with a high $\delta^{2} \mathrm{H}$ value) are additive to the tendency of mangroves to

492 fractionate ${ }^{2} \mathrm{H}$ from ${ }^{1} \mathrm{H}$ to a greater extent at high salinity, and stable $\delta^{2} \mathrm{H}_{\text {water }}$ values across

493 salinity treatments in the greenhouse may therefore have resulted in weaker observed

494 relationships between $\alpha^{2} \mathrm{H}_{\text {lipid-water }}$ and salinity.

495 Other differences between natural environments and greenhouse settings such as temperature

496 may have contributed to different trends between uncultivated and greenhouse-cultivated

497 mangrove-derived lipids and salinity. It is unclear what effect temperature would have on

498 hydrogen isotope fractionation in mangroves, as this has not been studied directly. However, in

499 growth chamber experiments with other vascular plants, temperature did not affect hydrogen

500 isotope fractionation during lipid biosynthesis (Zhou et al., 2011). Additionally, since all

501 mangroves in our study were exposed to the same temperature conditions regardless of salinity

502 treatment, any possible effect of temperature on $\alpha^{2} \mathrm{H}$ would have affected plants in all salinity

503 treatments equally. However, it may be possible that cold temperature imposed significant cold

504 stress on all greenhouse plants so that the temperature effect outweighed changes in isotopic

505 fractionation due to differences in salinity, resulting in a different relationship between salinity

506 and $\delta^{2} \mathrm{H}_{\text {lipid }}$ from that of uncultivated trees.

507 It is also possible that parameters not controlled in the greenhouse experiments, such as

508 nutrient availability or water temperature, co-varied with salinity in the field sites and were

509 responsible for the observed relationships between salinity and $\alpha^{2} \mathrm{H}_{\text {lipid-water. However, }}$

510 considering that the same relationship between salinity and $\alpha^{2} \mathrm{H}_{\text {lipid-water }}$ has been observed across

511 diverse settings in the tropics and subtropics (Ladd and Sachs, 2012, 2015a, 2015b, 2017; He et

512 al., 2017), this seems unlikely. 
513 It is noteworthy that all $\delta^{2} \mathrm{H}_{\text {lipid }}$ values we report here from greenhouse-cultivated mangroves

514 are from $n-\mathrm{C}_{16}$ and $n-\mathrm{C}_{18}$ fatty acids, while the field studies focused on $n$-alkanes and

515 triterpenoids. This study focused on fatty acids as they have shorter residence time in leaves than

516 other lipid compounds and would reflect conditions at time of sampling more closely (Sachse et

517 al., 2009; Kahmen et al., 2011a; Gao et al., 2012). However, the significant correlation between

518 salinity and R. mangle $\delta^{2} \mathrm{H}_{\text {fatty acid }}$ (Fig. 3) and lack of any correlation between salinity and $R$.

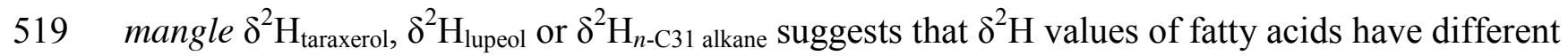

520 responses to salinity than do $n$-alkanes or triterpenoids (Supplementary Fig. S4). Therefore,

521 fractionation during biosynthesis of isoprenoids and longer-chain acetogenic lipids may be

522 responsible for a significant portion of the negative correlations between salinity and $\alpha^{2} \mathrm{H}_{\text {lipid-water }}$

523 for these compounds in uncultivated mangroves.

525 4.2.2. Influence of $\delta^{2} H_{l w}$ on $\delta^{2} H_{\text {fatty acid }}$

526 The relationship between salinity and $\delta^{2} \mathrm{H}$ values of leaf water $\left(\delta^{2} \mathrm{H}_{\mathrm{lw}}\right)$ can partially account

527 for enrichment of greenhouse-cultivated mangrove $\delta^{2} \mathrm{H}_{\text {fatty acid }}$ values with increasing salinity.

528 Plant leaf water is a major source of hydrogen in lipids produced by dicots, and $\delta^{2} \mathrm{H}_{\text {lw }}$ values

529 depend on variables including temperature, relative humidity, stomatal conductance,

530 transpiration rate, $\delta^{2} \mathrm{H}_{\text {water }}$ and $\delta^{2} \mathrm{H}_{\mathrm{xw}}$ (Schmidt et al., 2003; Kahmen et al., 2011a, 2013).

531 Therefore, if any of these variables are correlated with salinity, $\delta^{2} \mathrm{H}_{\mathrm{lw}}$ would also be expected to

532 vary with salinity, and lipids produced from leaf water will have different $\delta^{2} \mathrm{H}$ values.

533 The effects on $\delta^{2} \mathrm{H}_{\mathrm{lw}}$ of environmental parameters that vary with salinity (e.g., stomatal

534 conductance, $\delta^{2} \mathrm{H}_{\mathrm{xw}}$ and path length) were assessed with a Péclet-modified Craig-Gordon leaf

535 water isotope model (Kahmen et al., 2011b). $\delta^{2} \mathrm{H}_{\mathrm{lw}}$ values became enriched by $3 \%$ as stomatal 
536 conductance decreased across the range expected for salinity ranging between 5 and $30 \mathrm{ppt}$.

537 However, $\delta^{2} \mathrm{H}_{\mathrm{lw}}$ values at $30 \mathrm{ppt}$ were ${ }^{2} \mathrm{H}$-depleted by $2.7 \%$ due to $\delta^{2} \mathrm{H}_{\mathrm{xw}}$ decreasing by $7.6 \%$

538 across the $25 \mathrm{ppt}$ salinity range. In addition, at 30 ppt salinity, leaf water was ${ }^{2} \mathrm{H}$-depleted by $3 \%$

539 relative to $5 \mathrm{ppt}$ salinity, as path length increased from $120 \mathrm{~mm}$ to $280 \mathrm{~mm}$. Therefore, $\delta^{2} \mathrm{H}_{\mathrm{lw}}$

540 values were expected to be depleted by $2.7 \%$ at higher salinity, which is opposite to the observed

$541 \quad \delta^{2} H_{\text {fatty acid }}$ variability across salinities.

542 The combined effects of diurnally varying environmental parameters (e.g., air temperature,

543 relative humidity and $\delta^{2} \mathrm{H}_{\text {atmospheric vapor }}$ ) were assessed with the same leaf water model. Because

544 plants under high salt-stress display diurnal variations in WUE and photosynthetic activity

545 (Naidoo and Willert, 1995; Barr et al., 2009), and photosynthetic activity is related to fatty acid

546 production (Delwiche and Sharkey, 1993; Bao et al., 2000), preferential sourcing of lipid-

547 hydrogen from either an ${ }^{2} \mathrm{H}$-depleted daytime, or ${ }^{2} \mathrm{H}$-enriched nighttime leaf water pool could

548 impact $\delta^{2} \mathrm{H}_{\text {fatty acid }}$ values. Different species of mangroves (A. germinans, A. annulata and $R$.

549 mangle) growing under high salinity minimize evaporative water loss during mid-day, when both

550 air temperature and vapor pressure deficit are highest, by maintaining high photosynthetic rates

551 and low WUE in early morning (Naidoo and Willert, 1995; Barr et al., 2009). Newly fixed

552 carbon in plants is utilized for fatty acid or isoprene synthesis within 2 to 3 minutes (Delwiche

553 and Sharkey, 1993; Bao et al., 2000). If fixed carbon is used for fatty acid production very

554 quickly after it is assimilated, fatty acid production is also likely to be more active when the plant

555 is photosynthetically more active. Therefore, if the mangroves cultivated at high salinity in our

556 study exhibited highest photosynthetic performance in the morning to avoid water loss, the lipids

557 produced may have incorporated the $\delta^{2} \mathrm{H}$ composition of the nighttime leaf-water pool, which the

558 leaf water model predicts would be enriched by $16 \%$ relative to the daytime leaf-water pool. 
Mangroves growing at low salinity, on the other hand, would be relatively less sensitive to water

560 loss, and their lipids, by extension, less impacted by the ${ }^{2} \mathrm{H}$-enriched nighttime leaf-water pool,

561 which would result in more ${ }^{2} \mathrm{H}$-depleted lipids. Integrated with the result above, while plants

562 growing at high salinity draw from a leaf-water pool depleted by $3 \%$ relative to plants growing

563 at low salinity, if their lipid synthesis relies more on the enriched nighttime leaf-water pool, this

564 mechanism alone can account for about half of the entire $22-24 \%$ variability in $\delta^{2} \mathrm{H}_{\text {fatty acid }}$ of $R$.

565 mangle and $X$. granatum, or about a quarter of the $48-64 \%$ variability in $\delta^{2} \mathrm{H}_{\text {fatty acid }}$ of $R$.

566 apiculata.

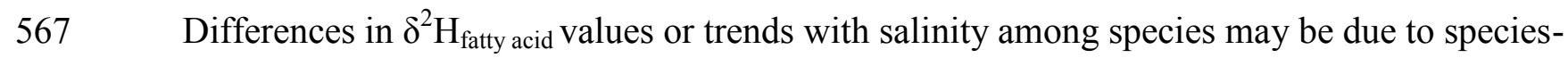

568 specific physiological processes for salt management that result in different leaf water potential

569 and leaf water enrichment. For example, effective salt secretion may influence the proportion of

570 more or less enriched leaf water pool during day and night that gets incorporated into lipids. In

571 our study, A. germinans and L. racemosa were the only species (of the five) that are known to

572 secrete salt from their leaves, and $\delta^{2} \mathrm{H}_{\text {fatty acid }}$ values of both species were uncorrelated with

573 salinity. High efficiency of salt secretion may be maintained by daily variations in transpiration

574 rates to keep xylem water potential very low during the day (Waisel et al., 1986). Therefore,

575 effective salt secretion may have helped A.germinans and L. racemosa in high salinity

576 treatments to be less sensitive to water loss during midday and less reliant on the enriched

577 nighttime leaf water pool relative to other species. Different biophysical processes of species

578 relying on the same salt management strategies may also affect water potentials. For example,

579 while A.germinans and Rhizophora spp. are both capable of accumulating salt in leaf vacuoles

580 and producing organic solutes, different types and concentrations of compatible solutes produced

581 by each species may also affect osmotic potentials to different degrees (Popp et al., 1985). In 
582 addition, distinct compatible solutes produced by different species may have a larger impact on

$583 \delta^{2} \mathrm{H}_{\text {lipid }}$ values than on $\delta^{2} \mathrm{H}_{\text {water }}$ values, as types and varying proportions of compatible solutes in

584 different salt marsh plants or mangrove species may result in varying contributions of hydrogen

585 in alkanes and fatty acids from photosynthetic and metabolic NADPH pools (Ladd and Sachs,

586 2015a; Eley et al., 2018).

\subsubsection{Potential reliance on stored carbohydrates}

589 The different relationship between lipid $\delta^{2} \mathrm{H}$ values and salinity from greenhouse-cultivated 590 and uncultivated mangroves may also be explained by greenhouse seedlings relying on stored 591 carbohydrates in large propagules during fatty acid synthesis. Hydrogen in lipids is derived from

592 leaf water and NADPH from either photosynthesis or sugar metabolism (Schmidt et al., 2003).

593 When plants synthesize lipids from stored carbohydrates, hydrogen can come from NADPH

594 either in the chloroplast (produced by photosynthesis) or in the cytosol (produced by sugar 595 metabolism), and photosynthetic NADPH is expected to be depleted in ${ }^{2} \mathrm{H}$ relative to metabolic 596 NADPH by as much as several hundred per mill (Schmidt et al., 2003). If photosynthetic activity 597 is limited during lipid synthesis, plants are more likely to rely on NADPH from the cytosol, 598 producing more ${ }^{2} \mathrm{H}$-enriched lipids (Schmidt et al., 2003; Cormier et al., 2018). Several studies 599 have observed ${ }^{2} \mathrm{H}$-enriched $n$-alkanes in leaf waxes of angiosperms that were photosynthetically 600 limited and relied on stored carbohydrates in large seeds (Newberry et al., 2015; Freimuth et al., 601 2017; Cormier et al., 2018).

602 Weights of mangrove seeds vary widely between species, but the two genera that showed 603 significant correlation between salinity and $\delta^{2} H_{\text {lipid }}$ in our study have very large seeds. $X$. 604 granatum seeds typically weigh $45-77 \mathrm{~g}$, while Rhizophora species propagules weigh 14-30 g 
605 (Rabinowitz, 1978; Smith, 1987; Gokhale and Chavan, 2002; Das and Ghose, 2003), and 40-

$60660 \%$ of the propagule mass is in the form of starch and sugar, potentially providing a long-lasting

607 carbohydrate source (Smith, 1987; Gunawan et al., 2013). If mangrove seedlings growing at high

608 salinity had limited photosynthetic capability and relied more on stored carbohydrates in

609 propagules for lipid production, contributions of $\mathrm{H}$ derived from the ${ }^{2} \mathrm{H}$-enriched metabolic

610 NADPH pool would be larger than that from the ${ }^{2} \mathrm{H}$-depleted photosynthetic NADPH pool, so

611 lipids would be more enriched in ${ }^{2} \mathrm{H}$ (Newberry et al., 2015; Cormier et al., 2018). This trend is

612 expected to be more pronounced in alkanes or isoprenoids than in fatty acids, which have

613 relatively short turnover times (Sachse et al., 2009; Kahmen et al., 2011a; Gao et al., 2012). In

614 our study, $\delta^{2} \mathrm{H}$ values of triterpenoids extracted from $R$. mangle leaves harvested in 2016 were

615 more depleted than those extracted from leaves harvested in 2014 (Fig. 5), supporting the

616 possibility that lipid-hydrogen was derived in part from carbohydrates stored in propagules and

617 large seeds. As the plants matured they presumably relied less on those maternal reserves and

618 more on their photosynthetic capacity.

619 In summary, the relationships between $\delta^{2} \mathrm{H}_{\text {lipid }}$ values and salinity were different for fatty

620 acids produced by three cultivated mangrove species (R.apiculata, $R$. mangle and X. granatum)

621 than for $n$-alkanes and triterpenols from seven mangrove species in diverse natural settings (Ladd

622 and Sachs, 2012, 2015a, 2015b, 2017; He at al., 2017). In order to be able to improve

623 uncertainties in the relationship between $\alpha^{2} \mathrm{H}$ and salinity using greenhouse-cultivated

624 mangroves, a better understanding of the impact of salinity on $\alpha^{2} \mathrm{H}$ is necessary. For instance, if

625 the difference is largely due to a lack of ${ }^{2} \mathrm{H}$-depleted freshwater sources in the greenhouse,

626 improved calibrations might only be possible if alternate freshwater sources can be provided in

627 the greenhouse. 
629 4.3. Implications of $\delta^{2} H$ and $\delta^{13} C_{\text {fatty acid }}$ measurements from greenhouse-cultivated mangroves $630 \quad$ for reconstructing precipitation rates

631 The use of coupled $\delta^{2} \mathrm{H}$ and $\delta^{13} \mathrm{C}$ values of mangrove lipids holds promise for quantitatively 632 reconstructing precipitation rates in the past, a climate parameter for which there are few proxies

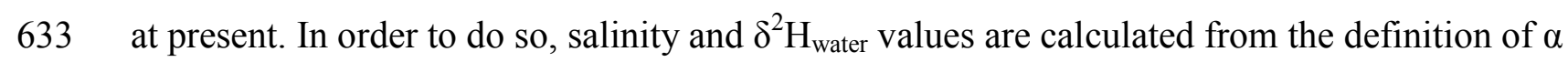
$634\left(\alpha^{2} \mathrm{H}=\left(\delta^{2} \mathrm{H}_{\text {lipid }}+1000\right) /\left(\delta^{2} \mathrm{H}_{\text {water }}+1000\right)\right.$ and $\left.\alpha^{13} \mathrm{C}=\left(\delta^{13} \mathrm{C}_{\text {lipid }}+1000\right) /\left(\delta^{13} \mathrm{C}_{\mathrm{atm}}+1000\right)\right)$ and the 635 linear relationships between $\alpha$ and salinity $\left(\alpha^{2} \mathrm{H}=\mathrm{m}_{2} \times \mathrm{S}+\mathrm{b}_{2}\right.$ and $\left.\alpha^{13} \mathrm{C}=\mathrm{m}_{13} \times \mathrm{S}+\mathrm{b}_{13}\right)$, as implied 636 in equations (1) and (2). Representative slopes and intercepts were $\mathrm{m}_{2}=-0.0015 \pm 0.000026, \mathrm{~b}_{2}$ $637=0.892 \pm 0.0057, \mathrm{~m}_{13}=0.00019 \pm 0.000053$ and $\mathrm{b}_{13}=0.970 \pm 0.0012$ (calibrations from $A$. 638 marina $n-\mathrm{C}_{31}$ alkanes; Ladd and Sachs, 2012, 2013). We assessed uncertainties in the derived

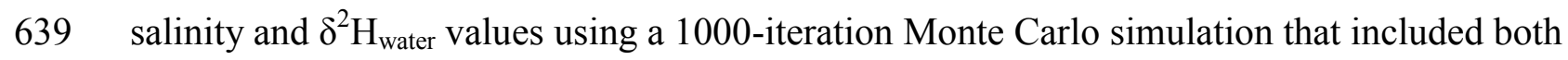
640 calibration and analytical uncertainties for both $\delta^{2} \mathrm{H}$ and $\delta^{13} \mathrm{C}$.

$$
\begin{aligned}
& \text { Salinity }=\left(\frac{\left(\delta^{13} \mathrm{C}_{\text {lipid }}+1000\right)}{\left(\delta^{13} \mathrm{C}_{\mathrm{atm}}+1000\right)}-\mathrm{b}_{13}\right) \times \frac{1}{\mathrm{~m}_{13}} \\
& \delta^{2} \mathrm{H}_{\text {water }}=\left(\frac{\left(\delta^{2} \mathrm{H}_{\text {lipid }}+1000\right)}{\frac{\mathrm{m}_{2}}{\mathrm{~m}_{13}}\left(\frac{\left(\delta^{13} \mathrm{Cl}_{\text {lipid }}+1000\right)}{\left(\delta^{13} \mathrm{C}_{\mathrm{atm}}+1000\right)}-\mathrm{b}_{13}\right)+\mathrm{b}_{2}}\right)-1000
\end{aligned}
$$

644 vs salinity would have on the uncertainty of the derived salinity and $\delta^{2} \mathrm{H}_{\text {water }}$ values, several

645 1000-iteration Monte Carlo analyses with a surrogate data point were performed $\left(\delta^{2} \mathrm{H}_{\text {lipid }}=-100\right.$

$646 \pm 5 \%, \delta^{13} \mathrm{C}_{\text {lipid }}=-30 \pm 0.3 \%$ o), assuming a $50 \%$ and $100 \%$ reduction in the calibration

647 uncertainties and propagating the reduced errors to calculate uncertainties in salinity and $\delta^{2} \mathrm{H}_{\text {water. }}$

648 Results of these analyses (Table 7) indicate that reducing uncertainty in the $\alpha^{13} \mathrm{C}-$ salinity

649 calibration alone can reduce as much uncertainty in the derived salinity and $\delta^{2} \mathrm{H}_{\text {water }}$ values as 
650 reducing uncertainties in both the $\alpha^{2} \mathrm{H}-$ salinity and $\alpha^{13} \mathrm{C}-$ salinity calibrations. Future work

651 should therefore focus on obtaining improved $\alpha^{13} \mathrm{C}$-salinity calibrations from both field and

652 laboratory-based studies, possibly by increasing the number of samples to be analyzed.

653 Future work should also focus on measuring $\mathrm{H}$ and $\mathrm{C}$ isotopes of source-specific

654 biomarkers. We have used slopes and intercepts from $n$ - $\mathrm{C}_{31}$ alkanes for the uncertainty analysis

655 above to demonstrate how the paired $\mathrm{H}$ and $\mathrm{C}$ isotope approach would work, and focused on $n$ -

$656 \mathrm{C}_{16}$ and $n$ - $\mathrm{C}_{18}$ fatty acid $\delta^{2} \mathrm{H}$ and $\delta^{13} \mathrm{C}$ measurements to gain more insight into the mechanisms

657 that control $\mathrm{H}$ and $\mathrm{C}$ isotope fractionation as a function of salinity in mangrove lipids. However,

$658 n$ - $\mathrm{C}_{16}, n$ - $\mathrm{C}_{18}$ fatty acids and $n$-alkanes are produced not only by mangroves, but also by terrestrial

659 vascular plants, phytoplankton, and bacteria (e.g., Bianchi and Canuel, 2011). Therefore, it

660 would be virtually impossible to discern whether fatty acids or $n$-alkanes in mangrove swamps

661 and coastal sediments originated from mangroves or other organisms. Because hydrogen and

662 carbon isotope fractionation in lipids produced by organisms other than mangroves may respond

663 differently to salinity, application of paired $\delta^{2} \mathrm{H}$ and $\delta^{13} \mathrm{C}$ of fatty acids or alkanes with unknown

664 sources cannot provide reasonable estimates of salinity and $\delta^{2} H_{\text {water. }}$. A promising alternative to

665 fatty acids and $n$-alkanes is taraxerol, which in mangroves is primarily produced by Rhizophora

666 spp. (Versteegh et al., 2004; Koch et al., 2005), which are dominant in many tropical mangrove

667 forests (Duke, 2006). Since taraxerol found in coastal tropical and subtropical sediments is likely

668 to be derived from mangroves, applying the paired $\delta^{2} \mathrm{H}$ and $\delta^{13} \mathrm{C}$ approach with taraxerol is a

669 promising approach for constructing past precipitation rates.

670 In addition, for future mangrove culturing studies that may be conducted to improve the

671 calibrations between salinity and $\delta^{2} \mathrm{H}$ or $\delta^{13} \mathrm{C}$ of mangrove-derived lipids, the culturing could

672 simulate field conditions more closely. For instance, temperature and relative humidity inside the 
673 greenhouse could be set higher to better mimic tropical climate conditions and protect trees from

674 possible cold stress. Also, transferring plants to larger pots more often would allow more space

675 for roots and prevent plant growth from possible root restriction by container sizes.

\section{5. Conclusions}

$678 \quad \delta^{13} \mathrm{C}$ and $\delta^{2} \mathrm{H}$ values of $n-\mathrm{C}_{16}$ and $n-\mathrm{C}_{18}$ fatty acids and $\delta^{13} \mathrm{C}$ values of bulk leaves in five 679 species of mangroves cultivated in salinity treatments of 5-30 ppt in the UW greenhouse were

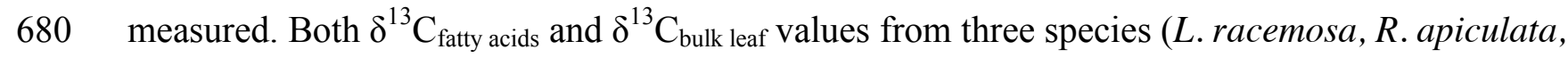
681 and $X$. granatum $)$ were positively correlated with salinity $(0.12-0.21 \%$ oppt and $0.10-0.22 \%$ p $/$ ppt, 682 respectively), due to increased $\mathrm{WUE}$ and ${ }^{13} \mathrm{C}$-enriched internal $\mathrm{CO}_{2}$ pool with increasing salinity. $683 \quad \delta^{2} \mathrm{H}_{\text {fatty acids }}$ values from three species (R. apiculata, $R$. mangle, and X. granatum) were 684 positively correlated with salinity $(0.47-1.25 \%$ oppt $)$, opposite to all field studies up to date, most 685 likely due to lack of ${ }^{2} \mathrm{H}$-depleted freshwater in the greenhouse. The positive relationship 686 observed between salinity and $\delta^{2} \mathrm{H}_{\text {fatty acids }}$ in greenhouse-cultivated mangroves may be caused by

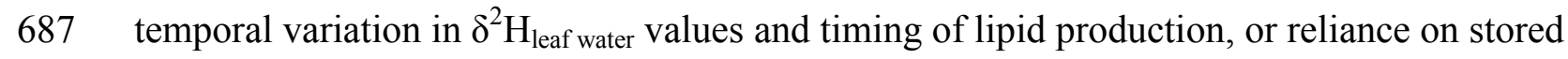
688 carbohydrates in seeds.

689 To use paired $\delta^{2} \mathrm{H}$ and $\delta^{13} \mathrm{C}$ measurements of mangrove lipids to quantitatively reconstruct 690 salinity and water isotopes, $\delta^{2} \mathrm{H}$ and $\delta^{13} \mathrm{C}$ values of mangrove-specific biomarkers such as 691 taraxerol should be measured. In addition, improving field and laboratory-based calibrations 692 between salinity and $\alpha^{13} \mathrm{C}$, partly by cultivating mangroves under an environment that resembles 693 tropical or subtropical climate more closely, will be important for future studies. At this point, 694 improving field and laboratory-based calibrations between salinity and $\alpha^{13} \mathrm{C}$ will be most likely 695 to reduce uncertainties in estimated salinity and water isotopes. 


\section{Acknowledgements}

698 This work was supported by the National Science Foundation under Grants No. EAR-1348396

699 and OCE-1736222 (J.P.S.). Erick Waguk assisted with seed collection in Micronesia. Doug

700 Ewing, June Landenburger, Marta Wolfshorndl, Colton Skavicus, Cyrena Thibodeau and Josh

701 Gregersen assisted with mangrove cultivation in the greenhouse. Matthew Wolhowe, Mark

702 Haught, Ashley Maloney and Tess Clinkingbeard provided assistance and advice with isotope

703 measurements and other analytical techniques. Paul Quay, Jodi Young, Steve Emerson and Liz

704 van Volkenberg provided constructive feedback and comments that greatly improved both this

705 study and this manuscript. Two anonymous reviewers provided helpful feedback and comments

706 that improved this manuscript. We are grateful for all their contributions.

707

\section{Associate Editor-Kliti Grice}

\section{$710 \quad$ References}

711 Alongi, D.M., Mukhopadhyay, S.K., 2015. Contribution of mangroves to coastal carbon cycling

712 in low latitude seas. Agricultural and Forest Meteorology 213, 266-272.

713 Arnold, T.E., Diefendorf, A.F., Brenner, M., Freeman, K.H., Baczynski, A.A., 2018. Climate

714 response of the Florida Peninsula to Heinrich events in the North Atlantic. Quaternary

$715 \quad$ Science Reviews 194, 1-11.

716 Arp, W.J., 1991. Effects of source- sink relations on photosynthetic acclimation to elevated $\mathrm{CO}_{2}$.

717 Plant, Cell and Environment 14, 869-875. 
Atwood, A.R., Sachs, J.P., 2014. Separating ITCZ- and ENSO-related rainfall changes in the Galápagos over the last 3 kyr using D/H ratios of multiple lipid biomarkers. Earth and Planetary Science Letters 404, 408-419.

Ball, M.C., Farquhar, G.D., 1983. Photosynthetic and stomatal responses of two mangrove species, Aegiceras corniculatum and Avicennia marina, to long term salinity and humidity conditions. Plant Physiology 74, 1-6.

Bao, X., Focke, M., Pollard, M., Ohlrogge, J., 2000. Understanding in vivo carbon precursor supply for fatty acid synthesis in leaf tissue. Plant Journal 22, 39-50.

Barr, J.G., Fuentes, J.D., Engel, V., Zieman, J.C., 2009. Physiological responses of red mangroves to the climate in the Florida Everglades. Journal of Geophysical Research: Biogeosciences 114, 1-13.

Bianchi, T.S., Canuel, E.A., 2011. Chemical Biomarkers in Aquatic Ecosystems. Princeton University Press, Princeton, New Jersey.

Biber, P.D., 2006. Measuring the effects of salinity stress in the red mangrove, Rhizophora mangle L. African Journal of Agricultural Research 1, 1-4.

Bony, S., Risi, C., Vimeux, F., 2008. Influence of convective processes on the isotopic composition $\left(\delta^{18} \mathrm{O}\right.$ and $\left.\delta \mathrm{D}\right)$ of precipitation and water vapor in the tropics: 1. Radiativeconvective equilibrium and Tropical Ocean-Global Atmosphere-Coupled OceanAtmosphere Response Experiment (TOGA-COARE) simulations. Journal of Geophysical Research Atmospheres 113, 1-21.

Brugnoli, E., Lauteri, M., Istituto, C.N.R., 1991. Effects of salinity on stomatal conductance, photosynthetic capacity, and carbon isotope discrimination of salt-tolerant (Gossypium 
hirsutum L.) and salt-sensitive (Phaseolus vulgaris L.) C3 non-halophytes. Plant Physiology 95, 628-635.

742 Cheng, H., Tam, N.F.Y., Wang, Y., Li, S., Chen, G., Ye, Z., 2012. Effects of copper on growth, radial oxygen loss and root permeability of seedlings of the mangroves Bruguiera gymnorrhiza and Rhizophora stylosa. Plant and Soil 359, 255-266.

Chiang, J.C.H., 2009. The tropics in paleoclimate. Annual Review of Earth and Planetary Sciences 37, 263-297.

Chivall, D., M'Boule, D., Sinke-Schoen, D., Sinninghe Damsté, J.S., Schouten, S., van der Meer, M.T.J., 2014. The effects of growth phase and salinity on the hydrogen isotopic composition of alkenones produced by coastal haptophyte algae. Geochimica et Cosmochimica Acta 140, 381-390.

751 Cormier, M.A., Werner, R.A., Sauer, P.E., Gröcke, D.R., Leuenberger, M.C., Wieloch, T., Schleucher, J., Kahmen, A., 2018. ${ }^{2} \mathrm{H}$-fractionations during the biosynthesis of carbohydrates and lipids imprint a metabolic signal on the $\delta^{2} \mathrm{H}$ values of plant organic compounds. New Phytologist 218, 479-491.

755 Dansgaard, W., 1964. Stable isotopes in precipitation. Tellus 16, 436-468.

756 Das, S., Ghose, M., 2003. Seed structure and germination pattern of some Indian mangroves with 757 taxonomic relevance. Taiwania 48, 287-298.

758 Delwiche, C.F., Sharkey, T.D., 1993. Rapid appearance of ${ }^{13} \mathrm{C}$ in biogenic isoprene when ${ }^{13} \mathrm{CO}_{2}$ 759 is fed to intact leaves. Plant, Cell and Environment 16, 587-591.

760 Douglas, P.M.J., Pagani, M., Brenner, M., Hodell, D.A., Curtis, J.H., 2012. Aridity and 761 vegetation composition are important determinants of leaf-wax $\delta \mathrm{D}$ values in southeastern 762 Mexico and Central America. Geochimica et Cosmochimica Acta 97, 24-45. 
Duke, N.C., 2006. Australia's Mangroves: The Authoritative Guide to Australia's Mangrove Plants. University of Queensland, Brisbane, Australia.

765

Eley, Y., White, J., Dawson, L., Hren, M., Pedentchouk, N., 2018. Variation in hydrogen isotope composition among salt marsh plant organic compounds highlights biochemical mechanisms controlling biosynthetic fractionation. Journal of Geophysical Research: Biogeosciences 123, 2645-2660.

Ellsworth, P.V., Ellsworth, P.Z., Anderson, W.T., Sternberg, L.S., 2013. The role of effective leaf mixing length in the relationship between the $\delta^{18} \mathrm{O}$ of stem cellulose and source water across a salinity gradient. Plant, Cell and Environment 36, 138-148.

Englebrecht, A.C., Sachs, J.P., 2005. Determination of sediment provenance at drift sites using hydrogen isotopes and unsaturation ratios in alkenones. Geochimica et Cosmochimica Acta $69,4253-4265$.

Ewe, S.M.L., Sternberg, L.D.S.L., Childers, D.L., 2007. Seasonal plant water uptake patterns in the saline southeast Everglades ecotone. Oecologia 152, 607-616.

Fairbanks, R.G., Evans, M.N., Rubenstone, J.L., Mortlock, R.A., Broad, K., Moore, M.D., Charles, C.D., 1997. Evaluating climate indices and their geochemical proxies measured in corals. Coral Reefs 16, S93-S100.

Farquhar, G., O'Leary, M., Berry, J., 1982. On the relationship between carbon isotope discrimination and the intercellular carbon dioxide concentration in leaves. Australian Journal of Plant Physiology 9, 121-137.

Farquhar, G.D., Ehlerginer, J.R., Hubick, K.T., 1989. Carbon isotope discrimination and photosynthesis. Annual Review of Plant Physiology 40, 503-537. 
Feakins, S.J., Sessions, A.L., 2010. Controls on the D/H ratios of plant leaf waxes in an arid ecosystem. Geochimica et Cosmochimica Acta 74, 2128-2141.

Flato, G., Marotzke, J., Abiodun, B., Braconnot, P., Chou, S.C., Collins, W., Cox, P., Driouech, F., Emori, S., Eyring, V., Forest, C., Gleckler, P., Guilyardi, E., Jakob, C., Kattsov, V., Reason, C., Rummukainen, M., 2013: Evaluation of climate models. In: Stocker, T.F., Qin, D., Plattner, G.-K., Tignor, M., Allen, S.K., Boschung, J., Nauels, A., Xia, Y., Bex, V., Midgley, P.M., (Eds), Climate Change 2013: The Physical Science Basis.

Contribution of Working Group I to the Fifth Assessment Report of the Intergovernmental Panel on Climate Change. Cambridge University Press, Cambridge, UK and New York, USA.

Freimuth, E.J., Diefendorf, A.F., Lowell, T.V., 2017. Hydrogen isotopes of $n$-alkanes and $n$ alkanoic acids as tracers of precipitation in a temperate forest and implications for paleorecords. Geochimica et Cosmochimica Acta 206, 166-183.

Gao, L., Burnier, A., Huang, Y., 2012. Quantifying instantaneous regeneration rates of plant leaf waxes using stable hydrogen isotope labeling. Rapid Communications in Mass Spectrometry 26, 115-122.

Giri, C., Ochieng, E., Tieszen, L.L., Zhu, Z., Singh, A., Loveland, T., Masek, J., Duke, N., 2011. Status and distribution of mangrove forests of the world using earth observation satellite data. Global Ecology and Biogeography 20, 154-159.

Gokhale, M.V., Chavan, N.S., 2002. Germination and growth performance of Xylocarpus granatum. In: Proceedings of the National Seminar on Creeks, Estuaries and Mangroves - Pollution and Conservation, November 2002, pp. 237-239. 
Greer, L., Swart, P.K., 2006. Decadal cyclicity of regional mid-Holocene precipitation: Evidence from Dominican coral proxies. Paleoceanography 21, 1-17.

809 Guenther, F., Aichner, B., Siegwolf, R., Xu, B., Yao, T., Gleixner, G., 2013. A synthesis of 810 hydrogen isotope variability and its hydrological significance at the Qinghai-Tibetan $811 \quad$ Plateau. Quaternary International 313-314, 3-16.

812 Gunawan, S., Darmawan, R., Nanda, M., Setiawan, A. D., Fansuri, H., 2013. Proximate composition of Xylocarpus moluccensis seeds and their oils. Industrial Crops and Products 41, 107-112.

Guy, R.D., Warne, P.G., Reid, D.M., 1988. Stable carbon isotope ratio as an index of water-use efficiency in $\mathrm{C} 3$ halophytes - possible relationship to strategies for osmotic adjustment.

In: Rundel P.W., Ehleringer J.R., Nagy K.A. (Eds), Stable Isotopes in Ecological Research. Ecological Studies (Analysis and Synthesis), vol 68. Springer, New York.

He, D., Ladd, S.N., Sachs, J.P., Jaffé, R., 2017. Inverse relationship between salinity and ${ }^{2} \mathrm{H} /{ }^{1} \mathrm{H}$ fractionation in leaf wax $n$-alkanes from Florida mangroves. Organic Geochemistry 110, $1-12$.

Heinzelmann, S.M., Chivall, D., M'Boule, D., Sinke-Schoen, D., Villanueva, L., Sinninghe Damsté, J.S., Schouten, S., Van der Meer, M.T.J., 2015a. Comparison of the effect of salinity on the $\mathrm{D} / \mathrm{H}$ ratio of fatty acids of heterotrophic and photoautotrophic microorganisms. FEMS Microbiology Letters 362, 1-6.

Heinzelmann, S.M., Villanueva, L., Sinke-Schoen, D., Sinninghe Damsté, J.S., Schouten, S., van der Meer, M.T.J., 2015b. Impact of metabolism and growth phase on the hydrogen isotopic composition of microbial fatty acids. Frontiers in Microbiology 6, 1-11. 
Huang, Y., Shuman, B., Wang, Y., Webb, T., 2004. Hydrogen isotope ratios of individual lipids in lake sediments as novel tracers of climatic and environmental change: A surface sediment test. Journal of Paleolimnology 31, 363-375.

Jennerjahn, T.C., Ittekkot, V., 2002. Relevance of mangroves for the production and deposition of organic matter along tropical continental margins. Naturwissenschaften 89, 23-30.

Jiang, Q., Roche, D., Monaco, T.A., Durham, S., 2006. Gas exchange, chlorophyll fluorescence parameters and carbon isotope discrimination of 14 barley genetic lines in response to salinity. Field Crops Research 96, 269-278.

Jones, P.D., Briffa, K.R., Osborn, T.J., Lough, J.M., Van Ommen, T.D., Vinther, B.M., Luterbacher, J., Wahl, E.R., Zwiers, F.W., Mann, M.E., Schmidt, G.A., Ammann, C.M., Buckley, B.M., Cobb, K.M., Esper, J., Goosse, H., Graham, N., Jansen, E., Kiefer, T., Kull, C., Küttel, M., Mosley-Thompson, E., Overpeck, J.T., Riedwyl, N., Schulz, M., Tudhope, A.W., Villalba, R., Wanner, H., Wolff, E., Xoplaki, E., 2009. High-resolution paleoclimatology of the last millennium: A review of current status and future prospects. Holocene 19, 3-49.

Kahmen, A., Dawson, T.E., Vieth, A., Sachse, D., 2011a. Leaf wax $n$-alkane $\delta D$ values are determined early in the ontogeny of Populus trichocarpa leaves when grown under controlled environmental conditions. Plant, Cell and Environment 34, 1639-1651.

Kahmen, A., Sachse, D., Arndt, S.K., Tu, K.P., Farrington, H., Vitousek, P.M., Dawson, T.E., 2011b. Cellulose $\delta^{18} \mathrm{O}$ is an index of leaf-to-air vapor pressure difference (VPD) in tropical plants. Proceedings of the National Academy of Sciences 108, 1981-1986.

Kahmen, A., Hoffmann, B., Schefuß, E., Arndt, S.K., Cernusak, L.A., West, J.B., Sachse, D., 2013. Leaf water deuterium enrichment shapes leaf wax $n$-alkane $\delta \mathrm{D}$ values of 
angiosperm plants II: Observational evidence and global implications. Geochimica et Cosmochimica Acta 111, 50-63.

854 Kasai, M., Koide, K., Ichikawa, Y., 2012. Effect of pot size on various characteristics related to photosynthetic matter production in soybean plants. International Journal of Agronomy $2012,1-7$.

Koch, B.P., Harder, J., Lara, R.J., Kattner, G., 2005. The effect of selective microbial degradation on the composition of mangrove derived pentacyclic triterpenols in surface sediments. Organic Geochemistry 36, 273-285.

Konecky, B.L., Russell, J.M., Rodysill, J.R., Vuille, M., Bijaksana, S., Huang, Y., 2013. Intensification of southwestern Indonesian rainfall over the past millennium. Geophysical

Krauss, K.W., Allen, J.A., 2003. Influences of salinity and shade on seedling photosynthesis and growth of two mangrove species, Rhizophora mangle and Bruguiera sexangula, introduced to Hawaii. Aquatic Botany 77, 311-324.

Ladd, S.N., Sachs, J.P., 2012. Inverse relationship between salinity and $n$-alkane $\delta D$ values in the mangrove Avicennia marina. Organic Geochemistry 48, 25-36.

Ladd, S.N., Sachs, J.P., 2013. Positive correlation between salinity and $n$-alkane $\delta^{13} \mathrm{C}$ values in the mangrove Avicennia marina. Organic Geochemistry 64, 1-8.

872 Ladd, S.N., Sachs, J.P., 2015b. Influence of salinity on hydrogen isotope fractionation in Rhizophora mangroves from Micronesia. Geochimica et Cosmochimica Acta 168, 206221. 
875 Ladd, S.N., Sachs, J.P., 2017. ${ }^{2} \mathrm{H} /{ }^{1} \mathrm{H}$ fractionation in lipids of the mangrove Bruguiera

876 gymnorhiza increases with salinity in marine lakes of Palau. Geochimica et

$877 \quad$ Cosmochimica Acta 204, 300-312.

878 Ladd, S.N., Nelson, D.B., Schubert, C.J., Dubois, N., 2018. Lipid compound classes display

879 diverging hydrogen isotope responses in lakes along a nutrient gradient. Geochimica et

$880 \quad$ Cosmochimica Acta 237, 103-119.

881 Lambs, L., Muller, E., Fromard, F., 2008. Determination of ${ }^{13} \mathrm{C} /{ }^{12} \mathrm{C}$ ratios of endogenous urinary

882 steroids: method validation, reference population and application to doping control

883 purposes. Rapid Communications in Mass Spectrometry 22, 2161-2175.

884 Li, Z.H., Labbé, N., Driese, S.G., Grissino-Mayer, H.D., 2011. Micro-scale analysis of tree-ring

$885 \quad \delta^{18} \mathrm{O}$ and $\delta^{13} \mathrm{C}$ on $\alpha$-cellulose spline reveals high-resolution intra-annual climate

886 variability and tropical cyclone activity. Chemical Geology 284, 138-147.

887 Liang, J., Wright, J. S., Cui, X., Sternberg, L., Gan, W., Lin, G., 2018. Leaf anatomical traits

888 determine the ${ }^{18} \mathrm{O}$ enrichment of leaf water in coastal halophytes. Plant, Cell and

$889 \quad$ Environment 41, 2744-2757.

890 Lin, G.H., Sternberg, L., 1992. Effect of growth form, salinity, nutrient and sulfide on photosynthesis, carbon isotope discrimination and growth of red mangrove (Rhizophora

893 Lin, G., Sternberg, L., 1993. Hydrogen isotopic fractionation by plant roots during water uptake in coastal wetland plants. In: Ehleringer, J.R., Hall, A.E., Farquhar, G.D. (Eds), Stable Isotopes and Plant Carbon-Water Relations. Academic Press, San Diego, pp. 497-510. in water sources accessed by mangrove tree species. Hydrobiologia 803, 133-145. 
M’boule, D., Chivall, D., Sinke-Schoen, D., Sinninghe Damsté, J.S., Schouten, S., Van der Meer, M.T.J., 2014. Salinity dependent hydrogen isotope fractionation in alkenones produced by coastal and open ocean haptophyte algae. Geochimica et Cosmochimica Acta 130, 126-135.

Maloney, A.E., Shinneman, A.L.C., Hemeon, K., Sachs, J.P., 2016. Exploring lipid ${ }^{2} \mathrm{H} /{ }^{1} \mathrm{H}$ fractionation mechanisms in response to salinity with continuous cultures of the diatom Thalassiosira pseudonana. Organic Geochemistry 101, 154-165.

Maloney, A.E., Nelson, D.B., Richey, J.N., Prebble, M., Sear, D.A., Hassall, J.D., Langdon, P.G., Croudace, I.W., Zawadzki, A., Sachs, J.P., 2019. Reconstructing precipitation in the tropical South Pacific from dinosterol ${ }^{2} \mathrm{H} /{ }^{1} \mathrm{H}$ ratios in lake sediment. Geochimica et Cosmochimica Acta 245, 190-206.

Martin, K.C., Bruhn, D., Lovelock, C.E., Feller, I.C., Evans, J.R., Ball, M.C., 2010. Nitrogen fertilization enhances water-use efficiency in a saline environment. Plant, Cell and Environment 33, 344-357.

Naidoo, G., von Willert, D.J., 1995. Diurnal gas exchange characteristics and water use efficiency of three salt-secreting mangroves at low and high salinities. Hydrobiologia $295,13-22$.

Nelson, D.B., Sachs, J.P., 2014. The influence of salinity on D/H fractionation in dinosterol and brassicasterol from globally distributed saline and hypersaline lakes. Geochimica et Cosmochimica Acta 133, 325-339.

Nelson, D.B., Sachs, J.P., 2016. Galápagos hydroclimate of the Common Era from paired microalgal and mangrove biomarker ${ }^{2} \mathrm{H} /{ }^{1} \mathrm{H}$ values. Proceedings of the National Academy of Sciences 113, 3476-3481. 
921 NeSmith, D.S., Duval, J.R., 1998. The effect of container size. HortTechnology 8, 495-498.

922 Newberry, S.L., Kahmen, A., Dennis, P., Grant, A., 2015. $n$-alkane biosynthetic hydrogen

923 isotope fractionation is not constant throughout the growing season in the riparian tree

$924 \quad$ Salix viminalis. Geochimica et Cosmochimica Acta 165, 75-85.

925 Niedermeyer, E.M., Schefuß, E., Sessions, A.L., Mulitza, S., Mollenhauer, G., Schulz, M.,

926 Wefer, G., 2010. Orbital- and millennial-scale changes in the hydrologic cycle and

927 vegetation in the western African Sahel: Insights from individual plant wax $\delta \mathrm{D}$ and $\delta^{13} \mathrm{C}$.

928 Quaternary Science Reviews 29, 2996-3005.

929 Pahnke, K., Sachs, J.P., Keigwin, L., Timmermann, A., Xie, S.P., 2007. Eastern tropical Pacific

930 hydrologic changes during the past 27,000 years from $\mathrm{D} / \mathrm{H}$ ratios in alkenones.

$931 \quad$ Paleoceanography 22, 1-15.

932 Parida, A.K., Jha, B., 2010. Salt tolerance mechanisms in mangroves: a review. Trees 24, 199-

933217.

934 Pfeiffer, M., Timm, O., Dullo, W.C., Garbe-Schönberg, D., 2006. Paired coral Sr/Ca and $\delta^{18} \mathrm{O}$

935 records from the Chagos Archipelago: Late twentieth century warming affects rainfall

936 variability in the tropical Indian Ocean. Geology 34, 1069-1072.

937 Pierrehumbert, R.T., 2000. Climate change and the tropical Pacific: The sleeping dragon wakes.

$938 \quad$ Proceedings of the National Academy of Sciences 97, 1355-1358.

939 Polissar, P.J., Freeman, K.H., 2010. Effects of aridity and vegetation on plant-wax $\delta$ D in modern $940 \quad$ lake sediments. Geochimica et Cosmochimica Acta 74, 5785-5797.

941 Poorter, H., Bühler, J., Van Dusschoten, D., Climent, J., Postma, J.A., 2012. Pot size matters: A 942 meta-analysis of the effects of rooting volume on plant growth. Functional Plant Biology $943 \quad 39,839-850$. 
944 Popp, M., Larher, F., Weigel, P., 1985. Osmotic adaption in Australian mangroves. In: Ecology 945 of Coastal Vegetation. Springer, Dordrecht, pp. 247-253.

946 Rabinowitz, D., 1978. Mortality and initial propagule size in mangrove seedlings in Panama.

$947 \quad$ Journal of Ecology 66, 45-51.

948 Reef, R., Lovelock, C.E., 2015. Regulation of water balance in mangroves. Annals of Botany $949 \quad 115,385-395$.

950 Richey, J.N., Sachs, J.P., 2016. Precipitation changes in the western tropical Pacific over the past millennium. Geology 44, 671-674.

952 Risi, C., Bony, S., Vimeux, F., 2008. Influence of convective processes on the isotopic composition $\left(\delta^{18} \mathrm{O}\right.$ and $\left.\delta \mathrm{D}\right)$ of precipitation and water vapor in the tropics: 2. Physical interpretation of the amount effect. Journal of Geophysical Research Atmospheres 113,

959 Sachs, J.P., Sachse, D., Smittenberg, R.H., Zhang, Z., Battisti, D.S., Golubic, S., 2009.

Rivelli, A.R., James, R.A., Munns, R., Condon, A.G., 2002. Effect of salinity on water relations and growth of wheat genotypes with contrasting sodium uptake. Functional Plant Biology Southward movement of the Pacific intertropical convergence zone AD 1400-1850.

962 Sachs, J.P., Schwab, V.F., 2011. Hydrogen isotopes in dinosterol from the Chesapeake Bay estuary. Geochimica et Cosmochimica Acta 75, 444-459.

964 Sachs, J.P., Kawka, O.E., 2015. The influence of growth rate on ${ }^{2} \mathrm{H} /{ }^{1} \mathrm{H}$ fractionation in continuous cultures of the coccolithophorid Emiliania huxleyi and the diatom Thalassiosira pseudonana. PLoS ONE 10, 1-27. 
967 Sachs, J.P., Maloney, A.E., Gregersen, J., Paschall, C., 2016. Effect of salinity on ${ }^{2} \mathrm{H} /{ }^{1} \mathrm{H}$ 968 fractionation in lipids from continuous cultures of the coccolithophorid Emiliania 969 huxleyi. Geochimica et Cosmochimica Acta 189, 96-109.

970 Sachs, J.P., Maloney, A.E., Gregersen, J., 2017. Effect of light on ${ }^{2} \mathrm{H} /{ }^{1} \mathrm{H}$ fractionation in lipids 971 from continuous cultures of the diatom Thalassiosira pseudonana. Geochimica et $972 \quad$ Cosmochimica Acta 209, 204-215.

973 Sachs, J.P., Stein, R., Maloney, A.E., Wolhowe, M., Fahl, K., Nam, S.I., 2018. An Arctic Ocean 974 paleosalinity proxy from $\delta^{2} \mathrm{H}$ of palmitic acid provides evidence for deglacial Mackenzie 975 River flood events. Quaternary Science Reviews 198, 76-90.

976 Sachse, D., Sachs, J.P., 2008. Inverse relationship between D/H fractionation in cyanobacterial 977 lipids and salinity in Christmas Island saline ponds. Geochimica et Cosmochimica Acta 978 72, 793-806.Sachse, D., Kahmen, A., Gleixner, G., 2009. Significant seasonal variation

982 Sachse, D., Radke, J., Gleixner, G., 2004. Hydrogen isotope ratios of recent lacustrine 983 sedimentary $n$-alkanes record modern climate variability. Geochimica et Cosmochimica

985 Sachse, D., Billault, I., Bowen, G.J., Chikaraishi, Y., Dawson, T.E., Feakins, S.J., Freeman, 986 K.H., Magill, C.R., McInerney, F.A., van der Meer, M.T.J., Polissar, P., Robins, R.J., 987 Sachs, J.P., Schmidt, H.-L., Sessions, A.L., White, J.W.C., West, J.B., Kahmen, A., 2012. 988 Molecular Paleohydrology: Interpreting the hydrogen-isotopic composition of lipid 
biomarkers from photosynthesizing organisms. Annual Review of Earth and Planetary Sciences 40, 221-249.

991 Santini, N.S., Reef, R., Lockington, D.A., Lovelock, C.E., 2015. The use of fresh and saline water sources by the mangrove Avicennia marina. Hydrobiologia 745, 59-68.

Sauer, P.E., Eglinton, T.I., Hayes, J.M., Schimmelmann, A., Sessions, A.L., 2001. Compoundspecific D/H ratios of lipid biomarkers from sediments as a proxy for environmental and

Schefuß, E., Schouten, S., Schneider, R.R., 2005. Climatic controls on central African hydrology climatic conditions. Geochimica et Cosmochimica Acta 65, 213-222.

Schmidt, H.L., Werner, R.A., Eisenreich, W., 2003. Systematics of ${ }^{2}$ H patterns in natural compounds and its importance for the elucidation of biosynthetic pathways.

Schouten, S., Ossebaar, J., Schreiber, K., Kienhuis, M.V.M., Langer, G., Benthien, A., Bijma, J., 1002 2006. The effect of temperature, salinity and growth rate on the stable hydrogen isotopic composition of long chain alkenones produced by Emiliania huxleyi and Gephyrocapsa oceanica. Biogeosciences 3, 113-119.

Smith III, T.J., 1987. Seed predation in relation to tree dominance and distribution in mangrove forests. Ecology 68, 266-273.

Smith, F.A., Freeman, K.H., 2006. Influence of physiology and climate on $\delta D$ of leaf wax $n$ alkanes from C3 and C4 grasses. Geochimica et Cosmochimica Acta 70, 1172-1187. of the marine lakes of Palau as proxies for West Pacific Warm Pool hydrologic variability. Quaternary Science Reviews 30, 921-933. 
1012 Sobrado, M.A., 2000a. Leaf photosynthesis of the mangrove Avicennia germinans as affected by $1013 \quad \mathrm{NaCl}$. Photosynthetica 36, 547-555.

1014 Sobrado, M.A., 2000b. Relation of water transport to leaf gas exchange properties in three 1015 mangrove species. Trees 14, 258-262.

1016 Song, X., Barbour, M.M., Farquhar, G.D., Vann, D.R., Helliker, B.R., 2013. Transpiration rate 1017 relates to within- and across- species variations in effective path length in a leaf water 1018 model of oxygen isotope enrichment. Plant, Cell and Environment 36, 1338-1351.

1019 Steppe, K., Vandegehuchte, M.W., Van de Wal, B.A.E., Hoste, P., Guyot, A., Lovelock, C.E., 1020 Lockington, D.A., 2018. Direct uptake of canopy rainwater causes turgor-driven growth 1021

1022 Sternberg, L.D.S.L., Swart, P.K., 1987. Utilization of freshwater and ocean water by coastal 1023 plants of southern Florida. Ecology 68, 1898-1905.

1024 Sun, Q., Miao, C., Duan, Q., Ashouri, H., Sorooshian, S., Hsu, K.L., 2017. A review of global 1025 precipitation datasets: data sources, estimation, and intercomparisons. Reviews of 1026 Geophysics 56, 79-107.

1027 Thompson, L.G., Mosley-Thompson, E., Bolzan, J.F., Koci, B.R., 1985. A 1500-year record of 1028 tropical precipitation in ice cores from the Quelccaya Ice Cap, Peru. Science 229, 9711029973.

1030 Thompson, L.G., Mosley-Thompson, E., Davis, M.E., Zagorodnov, V.S., Howat, I.M., 1031 Mikhalenko, V.N., Lin, P.N., 2013. Annually resolved ice core records of tropical climate 1032 variability over the past $\sim 1800$ years. Science $340,945-950$. 
1033 Tierney, J.E., Russell, J.M., Huang, Y., Sinninghe Damsté, J.S., Hopmans, E.C., Cohen, A.S.,

1034 2008. Northern hemisphere controls on tropical southeast African climate during the past

103560,000 years. Science 322, 252-255.

1036 Tipple, B.J., Berke, M.A., Doman, C.E., Khachaturyan, S., Ehleringer, J.R., 2013. Leaf-wax n-

1037 alkanes record the plant-water environment at leaf flush. Proceedings of the National

1038 Academy of Sciences 110, 2659-2664.

1039 Tipple, B.J., Pagani, M., 2013. Environmental control on eastern broadleaf forest species' leaf

1040 wax distributions and D/H ratios. Geochimica et Cosmochimica Acta 111, 64-77.

1041 Tiwari, M., Ramesh, R., Somayajulu, B.L.K., Jull, A.J.T., Burr, G.S., 2006. Paleomonsoon

1042 precipitation deduced from a sediment core from the equatorial Indian Ocean. Geo-

$1043 \quad$ Marine Letters 26, 23-30.

1044 van der Meer, M.T.J., Benthien, A., French, K.L., Epping, E., Zondervan, I., Reichart, G.J.,

1045 Bijma, J., Sinninghe Damsté, J.S., Schouten, S., 2015. Large effect of irradiance on

1046 hydrogen isotope fractionation of alkenones in Emiliania huxleyi. Geochimica et

1047 Cosmochimica Acta 160, 16-24.

1048 Versteegh, G.J.M., Schefuß, E., Dupont, L., Marret, F., Sinninghe Damsté, J.S., Jansen, J.H.F.,

1049 2004. Taraxerol and Rhizophora pollen as proxies for tracking past mangrove

1050 ecosystems. Geochimica et Cosmochimica Acta 68, 411-422.

1051 Vovides, A.G., Vogt, J., Kollert, A., Berger, U., Grueters, U., Peters, R., Lara-Domínguez, A.L.,

1052 López-Portillo, J., 2014. Morphological plasticity in mangrove trees: salinity-related

1053 changes in the allometry of Avicennia germinans. Trees 28, 1413-1425.

1054 Waisel, Y., Eshel, A., Agami, M., 1986. Salt balance of leaves of the mangrove Avicennia

1055 marina. Physiologia Plantarum 67, 67-72. 
1056 Wei, L., Lockington, D.A., Poh, S.C., Gasparon, M., Lovelock, C.E., 2013. Water use patterns of 1057 estuarine vegetation in a tidal creek system. Oecologia 172, 485-494.

1058 Weldeab, S., Lea, D.W., Schneider, R.R., Andersen, N., 2007. 155,000 years of West African 1059 monsoon and ocean thermal evolution. Science 316, 1303-1307.

1060 Wohl, E., Barros, A., Brunsell, N., Chappell, N.A., Coe, M., Giambelluca, T., Goldsmith, S.,

1061 Harmon, R., Hendrickx, J.M.H., Juvik, J., McDonnell, J., Ogden, F., 2012. The

1062 hydrology of the humid tropics. Nature Climate Change 2, 655-662.

1063 Wolhowe, M.D., Prahl, F.G., Probert, I., Maldonado, M., 2009. Growth phase dependent 1064 hydrogen isotopic fractionation in alkenone-producing haptophytes. Biogeosciences 6, 1065 1681-1694.

1066 Yang, H., Pagani, M., Briggs, D.E.G., Equiza, M.A., Jagels, R., Leng, Q., Lepage, B.A., 2009. 1067 Carbon and hydrogen isotope fractionation under continuous light: implications for 1068 paleoenvironmental interpretations of the High Arctic during Paleogene warming. $1069 \quad$ Oecologia 160, 461-470.

1070 Zhang, Z., Sachs, J.P., 2007. Hydrogen isotope fractionation in freshwater algae: I. Variations $1071 \quad$ among lipids and species. Organic Geochemistry 38, 582-608.

1072 Zhang, X., Zwiers, F.W., Hegerl, G.C., Lambert, F.H., Gillett, N.P., Solomon, S., Stott, P.A., 1073 Nozawa, T., 2007. Detection of human influence on twentieth-century precipitation $1074 \quad$ trends. Nature 448, 461-465.

1075 Zhang, Z., Sachs, J.P., Marchetti, A., 2009. Hydrogen isotope fractionation in freshwater and 1076 marine algae: II. Temperature and nitrogen limited growth rate effects. Organic 1077 Geochemistry 40, 428-439. 
1078 Zhang, Z., Leduc, G., Sachs, J.P., 2014. El Niño evolution during the Holocene revealed by a 1079 biomarker rain gauge in the Galápagos Islands. Earth and Planetary Science Letters 404, $1080 \quad 420-434$.

1081 Zhou, Y., Grice, K., Chikaraishi, Y., Stuart-Williams, H., Farquhar, G.D., Ohkouchi, N., 2011.

1082 Temperature effect on leaf water deuterium enrichment and isotopic fractionation during 1083 leaf lipid biosynthesis: results from controlled growth of $\mathrm{C}_{3}$ and $\mathrm{C}_{4}$ land plants.

$1084 \quad$ Phytochemistry 72, 207-213.

1085

1086

1087

1088 Figure captions

1089

1090 Fig. 1. Relationships between salinity and $\delta^{13} \mathrm{C}_{\text {fatty acid }}$ in mangrove leaf lipids. Panels only show 1091 species and compounds that display significant relationship $(\mathrm{p}<0.05)$. All panels include the 1092 regression lines (colored solid lines, labeled “OLS”), regression lines from Monte Carlo analysis 1093 (gray dashed lines, labeled "OLS+MC") and 95\% confidence intervals (gray shaded areas). Error 1094 bars that are not displayed are smaller than the plot marker size.

1095

1096 Fig. 2. Relationships between salinity and $\delta^{13} \mathrm{C}_{\text {bulk leaf }}$ in mangrove leaf lipids. Panels only show 1097 species that display significant relationship $(\mathrm{p}<0.05)$. All panels show the regression lines 1098 (colored dashed lines) and 95\% confidence intervals (gray shaded areas). Error bars that are not 1099 displayed are smaller than the plot marker size. 
1101 Fig. 3. Relationships between salinity and $\delta^{2} \mathrm{H}_{\text {fatty acid }}$ in mangrove leaf lipids. Panels only show 1102 species and compounds that display significant relationship $(\mathrm{p}<0.05)$. All panels include the 1103 regression lines (colored solid lines), regression lines from Monte Carlo analysis (gray dashed

1104 lines) and 95\% confidence intervals (gray shaded areas). Error bars that are not displayed are 1105 smaller than the plot marker size.

1107 Fig. 4. Relationships between salinity and $\alpha^{2} \mathrm{H}_{\text {lipid-water }}$ in mangrove leaf lipids. Panels only show 1108 species and compounds that display significant relationship $(\mathrm{p}<0.05)$. All panels include the 1109 regression line (colored solid lines), regression line from Monte Carlo analysis (gray dashed 1110 lines) and 95\% confidence intervals (gray shaded areas). Error bars in each panel represent

1111 propagated uncertainties from $\delta^{2} \mathrm{H}_{\text {lipid }}$ and $\delta^{2} \mathrm{H}_{\text {water }}$ measurements, and those that are not displayed 1112 are smaller than the plot marker size.

1114 Fig. 5. Relationships between salinity and $\delta^{2} \mathrm{H}_{\text {triterpenoids }}$ in $R$. mangle leaf lipids. Y axis values 1115 show the fractionation between lipids harvested in 2016 and $2014\left(\varepsilon_{2016-2014}\right)$. Red solid line $\left(\delta^{2} \mathrm{H}\right.$ $1116=0 \%$ ) is drawn for reference. Error bars that are not displayed are smaller than the plot marker 1117 size.

1119 Tables

1120 Table 1 Types of mangroves cultivated in the UW greenhouse and their salt management 1121 strategies (Parida and Jha, 2010; Reef and Lovelock, 2015)

\begin{tabular}{lcccc}
\hline Mangrove Species & Exclude & Secrete & Accumulate & Salt tolerance level \\
Avicennia germinans & $\mathrm{X}$ & $\mathrm{X}$ & $\mathrm{X}$ & High
\end{tabular}




\begin{tabular}{|c|c|c|c|}
\hline Heritiera littoralis & $\mathrm{X}$ & & \\
\hline Laguncularia racemosa & $\mathrm{X}$ & $\mathrm{X}$ & \\
\hline Rhizophora apiculata & $\mathrm{X}$ & & $\mathrm{X}$ \\
\hline Rhizophora mangle & $\mathrm{X}$ & & $\mathrm{X}$ \\
\hline Xylocarpus granatum & & & $\mathrm{X}$ \\
\hline
\end{tabular}

1122

1123 
1124 Table 2 Leaf water model sensitivity tested by holding other variables constant while changing a

1125 single variable

\begin{tabular}{lccc}
\hline & Input & $\delta^{2} \mathrm{H}_{\mathrm{lw}}(\%)$ & Range of $\delta^{2} \mathrm{H}_{\mathrm{lw}}$ \\
Temperature $\left({ }^{\circ} \mathrm{C}\right)$ & $16 \pm 3$ to $23 \pm 3$ & $-31 \pm 3$ to $-38 \pm 3$ & $7 \%$ o \\
Relative humidity (\%) & $25 \pm 5$ to $90 \pm 5$ & $-28 \pm 11$ to $-39 \pm 4$ & $11 \%$ o \\
$\delta^{2} \mathrm{H}_{\text {atmospheric vapor }}(\%)$ & $-110 \pm 5$ to $-125 \pm 5$ & $-32 \pm 3$ to $-44 \pm 3$ & $12 \%$ o \\
Stomatal conductance $\left(\mathrm{g}_{\mathrm{s}} ; \mathrm{mol} / \mathrm{m}^{2} \mathrm{~s}\right)$ & $0.1 \pm 0.05$ to $0.4 \pm 0.05$ & $-41 \pm 3$ to $-38 \pm 3$ & $3 \%$ \\
Effective path length $(\mathrm{L} ; \mathrm{mm})$ & $150 \pm 50$ to $300 \pm 50$ & $-48 \pm 3$ to $-44 \pm 3$ & $4 \% 0$ \\
$\delta^{2} \mathrm{H}_{\text {xylem water }}(\%)$ & $-42 \pm 5$ to $-48 \pm 5$ & $-35 \pm 3$ to $-37 \pm 3$ & $2 \%$ o
\end{tabular}

1126

1127 
1128 Table 3 Inputs used for leaf water model to calculate $\delta^{2} \mathrm{H}_{\text {leaf water }}$ at 5 and $30 \mathrm{ppt}$ salinity levels

\begin{tabular}{ccccc}
\hline Salinity $(\mathrm{ppt})$ & $\mathrm{g}_{\mathrm{s}}\left(\mathrm{mol} / \mathrm{m}^{2} / \mathrm{s}\right)$ & $\mathrm{L}(\mathrm{mm})$ & $\delta^{2} \mathrm{H}_{\text {xylem water }}(\%)$ & $\delta^{2} \mathrm{H}_{\text {leaf water }}(\%)$ \\
5 & 0.35 & 120 & -42 & $-36.1 \pm 2.6$ \\
30 & 0.15 & 280 & -48 & $-38.9 \pm 3.0$ \\
\hline
\end{tabular}

1129

1130 
1131 Table 4 Inputs used for leaf water model to calculate $\delta^{2} \mathrm{H}_{\text {leaf water }}$ in daytime and nighttime

\begin{tabular}{|c|c|c|c|c|}
\hline & Temperature & Water vapor content & Relative humidity & $\delta^{2} \mathrm{H}_{\text {atmospheric vapor }}$ \\
\hline Day & $21 \pm 2{ }^{\circ} \mathrm{C}$ & $15000 \mathrm{ppm}$ & $0.97 \pm 0.10$ & $-125 \pm 5 \%$ \\
\hline Night & $17 \pm 2{ }^{\circ} \mathrm{C}$ & $12000 \mathrm{ppm}$ & $1.00 \pm 0.10$ & $-110 \pm 5 \%$ \\
\hline
\end{tabular}


Table 5 Results of linear regression analysis between salinity and $\delta^{2} \mathrm{H}_{\text {fatty acid }}$ or $\delta^{13} \mathrm{C}_{\text {fatty acid }}$ in all mangrove species and two fatty acid compounds

\begin{tabular}{|c|c|c|c|c|c|c|c|c|c|}
\hline Isotopes & Species & $\mathrm{N}$ & Compound & Slope & Intercept & MC slope & MC intercept & $\mathrm{R}^{2}$ & $\mathrm{p}$ \\
\hline \multirow[t]{9}{*}{$\delta^{2} \mathrm{H}_{\text {fatty acid }}$} & A. germinans & 10 & $n-\mathrm{C}_{16}$ & $-0.378 \pm 0.240$ & $-94.524 \pm 5.040$ & $-0.380 \pm 0.037$ & $-94.485 \pm 0.818$ & 0.237 & 0.153 \\
\hline & & & $n-\mathrm{C}_{18}$ & $-0.108 \pm 0.346$ & $-64.258 \pm 7.278$ & $-0.109 \pm 0.118$ & $-64.221 \pm 3.421$ & 0.012 & 0.764 \\
\hline & L. racemosa & 9 & $n-\mathrm{C}_{16}$ & $0.031 \pm 0.205$ & $-160.411 \pm 3.747$ & $0.039 \pm 0.055$ & $-160.428 \pm 0.783$ & 0.005 & 0.858 \\
\hline & & & $n-C_{18}$ & $0.506 \pm 0.396$ & $-148.100 \pm 7.231$ & $0.502 \pm 0.092$ & $-148.029 \pm 1.728$ & 0.189 & 0.242 \\
\hline & R. apiculata & 15 & $n-\mathrm{C}_{16}$ & $1.252 \pm 0.362$ & $-115.812 \pm 8.411$ & $1.253 \pm \mathbf{0 . 1 1 3}$ & $-115.816 \pm 2.769$ & 0.479 & 0.004 \\
\hline & & & $n-\mathrm{C}_{18}$ & $1.180 \pm 0.488$ & $-100.133 \pm 11.336$ & $1.179 \pm 0.113$ & $-100.069 \pm 2.582$ & 0.310 & 0.031 \\
\hline & R. mangle & 15 & $n-\mathrm{C}_{16}$ & $0.467 \pm 0.169$ & $-88.888 \pm 3.310$ & $0.474 \pm 0.142$ & $-88.970 \pm \mathbf{3 . 4 0 8}$ & 0.388 & 0.017 \\
\hline & X.granatum & 13 & $n-\mathrm{C}_{16}$ & $0.149 \pm 0.230$ & $-93.505 \pm 4.587$ & $0.148 \pm 0.038$ & $-93.506 \pm 0.842$ & 0.012 & 0.529 \\
\hline & & & $n-\mathrm{C}_{18}$ & $0.528 \pm 0.244$ & $-96.293 \pm 4.874$ & $0.529 \pm 0.060$ & $-96.307 \pm 1.396$ & 0.221 & 0.051 \\
\hline \multirow[t]{5}{*}{$\delta^{13} \mathrm{C}_{\text {fatty acid }}$} & A. germinans & 10 & $n-\mathrm{C}_{16}$ & $-0.007 \pm 0.081$ & $-33.969 \pm 1.712$ & $-0.007 \pm 0.034$ & $-33.983 \pm 0.708$ & 0.001 & 0.934 \\
\hline & & & $n-\mathrm{C}_{18}$ & $0.021 \pm 0.079$ & $-32.918 \pm 1.670$ & $0.020 \pm 0.029$ & $-32.896 \pm 0.612$ & 0.009 & 0.797 \\
\hline & L. racemosa & 9 & $n-\mathrm{C}_{16}$ & $0.179 \pm 0.119$ & $-39.167 \pm 2.173$ & $0.178 \pm 0.021$ & $-39.125 \pm 0.929$ & 0.244 & 0.176 \\
\hline & & & $n-\mathrm{C}_{18}$ & $\mathbf{0 . 2 0 7} \pm \mathbf{0 . 0 7 7}$ & $-37.554 \pm 1.408$ & $0.207 \pm 0.009$ & $-37.544 \pm 0.141$ & 0.508 & 0.031 \\
\hline & R. apiculata & 15 & $n-\mathrm{C}_{16}$ & $0.123 \pm \mathbf{0 . 0 4 4}$ & $-36.525 \pm 1.015$ & $0.123 \pm 0.008$ & $-36.525 \pm 0.185$ & 0.454 & 0.015 \\
\hline
\end{tabular}




\begin{tabular}{|c|c|c|c|c|c|c|c|c|c|}
\hline & & & $n-\mathrm{C}_{18}$ & $\mathbf{0 . 2 0 7} \pm \mathbf{0 . 0 5 2}$ & $-37.363 \pm 1.206$ & $\mathbf{0 . 2 0 7} \pm \mathbf{0 . 0 0 9}$ & $-37.366 \pm 0.210$ & 0.685 & 0.002 \\
\hline & R. mangle & 15 & $n-\mathrm{C}_{16}$ & $-0.026 \pm 0.024$ & $-39.308 \pm 0.460$ & $-0.026 \pm 0.008$ & $-39.329 \pm 0.176$ & 0.092 & 0.292 \\
\hline & $X$. granatum & 12 & $n-\mathrm{C}_{16}$ & $\mathbf{0 . 0 8 6} \pm \mathbf{0 . 0 3 7}$ & $-39.999 \pm 0.759$ & $\mathbf{0 . 0 8 6} \pm \mathbf{0 . 0 0 6}$ & $-39.998 \pm 0.116$ & 0.350 & 0.043 \\
\hline & & & $n-\mathrm{C}_{18}$ & $0.096 \pm 0.040$ & $-\mathbf{3 9 . 5 0 7} \pm \mathbf{0 . 8 3 1}$ & $0.095 \pm 0.009$ & $-39.496 \pm 0.185$ & 0.360 & 0.039 \\
\hline \multirow[t]{9}{*}{$\alpha^{2} \mathrm{H}_{\text {lipid-sw }}$} & A. germinans & 10 & $n-\mathrm{C}_{16}$ & $-0.00044 \pm 0.00028$ & $0.95037 \pm 0.00590$ & $-0.00049 \pm 0.00108$ & $0.95133 \pm 0.02713$ & 0.236 & 0.154 \\
\hline & & & $n-\mathrm{C}_{18}$ & $-0.00011 \pm 0.00035$ & $0.93485 \pm 0.00727$ & $-0.00010 \pm 0.00103$ & $0.93493 \pm 0.02635$ & 0.012 & 0.764 \\
\hline & L. racemosa & 9 & $n-\mathrm{C}_{16}$ & $0.00000 \pm 0.00025$ & $0.88130 \pm 0.00460$ & $0.00001 \pm 0.00105$ & $0.88097 \pm 0.02395$ & 0.000 & 0.992 \\
\hline & & & $n-\mathrm{C}_{18}$ & $0.00051 \pm 0.00040$ & $0.85115 \pm 0.00722$ & $0.00051 \pm 0.00107$ & $0.85079 \pm 0.02406$ & 0.189 & 0.242 \\
\hline & R. apiculata & 15 & $n-\mathrm{C}_{16}$ & $\mathbf{0 . 0 0 1 2 7} \pm \mathbf{0 . 0 0 0 3 6}$ & $0.92755 \pm \mathbf{0 . 0 0 8 4 5}$ & $\mathbf{0 . 0 0 1 2 3} \pm \mathbf{0 . 0 0 1 3 9}$ & $0.92808 \pm 0.03468$ & 0.484 & 0.004 \\
\hline & & & $n-\mathrm{C}_{18}$ & $0.00118 \pm 0.00049$ & $0.89903 \pm 0.01132$ & $0.00111 \pm 0.00138$ & $0.90059 \pm 0.03369$ & 0.310 & 0.031 \\
\hline & R. mangle & 15 & $n-\mathrm{C}_{16}$ & $\mathbf{0 . 0 0 0 4 7} \pm \mathbf{0 . 0 0 0 1 8}$ & $0.95583 \pm \mathbf{0 . 0 0 3 5 9}$ & $\mathbf{0 . 0 0 0 4 3} \pm \mathbf{0 . 0 0 1 7 7}$ & $0.95655 \pm 0.04262$ & 0.356 & 0.024 \\
\hline & $X$. granatum & 13 & $n-\mathrm{C}_{16}$ & $0.00003 \pm 0.00022$ & $0.95330 \pm 0.00455$ & $0.00002 \pm 0.00098$ & $0.95451 \pm 0.02385$ & 0.001 & 0.910 \\
\hline & & & $n-\mathrm{C}_{18}$ & $0.00039 \pm 0.00022$ & $0.90634 \pm 0.00458$ & $0.00034 \pm 0.00090$ & $0.90774 \pm 0.02227$ & 0.221 & 0.105 \\
\hline
\end{tabular}

Columns "MC slope" and "MC intercept" refer to results obtained from Monte Carlo approach. Relationships that are significant at the $\mathrm{p}<0.05$ level are indicated in bold letters. 
Table 6 Results of linear regressions between salinity and $\delta^{13} \mathrm{C}_{\text {bulk leaf }}$ in all five mangrove species

\begin{tabular}{ccccccc}
\hline Isotopes & Species & $\mathrm{N}$ & Slope & Intercept & $\mathrm{R}^{2}$ & $\mathrm{p}$ \\
$\delta^{13} \mathrm{C}_{\text {bulk leaf }}$ & A. germinans & 17 & $-0.030 \pm 0.050$ & $-28.445 \pm 1.024$ & 0.024 & 0.555 \\
& L. racemosa & $\mathbf{9}$ & $\mathbf{0 . 1 6 4} \pm \mathbf{0 . 0 2 0}$ & $\mathbf{- 3 0 . 8 5 8} \pm \mathbf{0 . 4 1 6}$ & $\mathbf{0 . 9 0 4}$ & $\mathbf{0 . 0 0 0}$ \\
& $\boldsymbol{R}$. apiculata & $\mathbf{1 7}$ & $\mathbf{0 . 2 2 0} \pm \mathbf{0 . 0 3 4}$ & $\mathbf{- 3 1 . 6 3 2} \pm \mathbf{0 . 7 6 7}$ & $\mathbf{0 . 7 3 7}$ & $\mathbf{0 . 0 0 0}$ \\
& R. mangle & 18 & $-0.070 \pm 0.030$ & $-25.845 \pm 0.567$ & 0.257 & 0.032 \\
& X. granatum & $\mathbf{2 0}$ & $\mathbf{0 . 1 0 1} \pm \mathbf{0 . 0 2 1}$ & $\mathbf{- 2 8 . 7 6 3} \pm \mathbf{0 . 4 4 8}$ & $\mathbf{0 . 5 6 0}$ & $\mathbf{0 . 0 0 0}$
\end{tabular}

Relationships that are significant at the $\mathrm{p}<0.05$ level are indicated in bold letters. 
Table 7 Uncertainties in salinity and $\delta^{2} H_{\text {water }}$ from Monte Carlo analysis with reduced uncertainties in current calibrations

\begin{tabular}{ccccc}
\hline & Salinity (ppt) & Salinity error (ppt) & $\delta^{2} \mathrm{H}_{\text {water }}(\%)$ & $\delta^{2} \mathrm{H}_{\text {water }}$ error (\%) \\
$100 \%$ uncertainty in both C and H & 43.07 & 3.08 & 87.93 & 6.09 \\
$50 \%$ uncertainty in both C and H & 43.18 & 1.69 & 88.13 & 3.34 \\
$50 \%$ uncertainty in only H & 43.16 & 3.26 & 88.11 & 6.47 \\
$50 \%$ uncertainty in only C & 43.21 & 1.70 & 88.18 & 3.36 \\
$0 \%$ uncertainty in both C and H & 43.26 & 0.52 & 88.26 & 1.02 \\
\hline
\end{tabular}



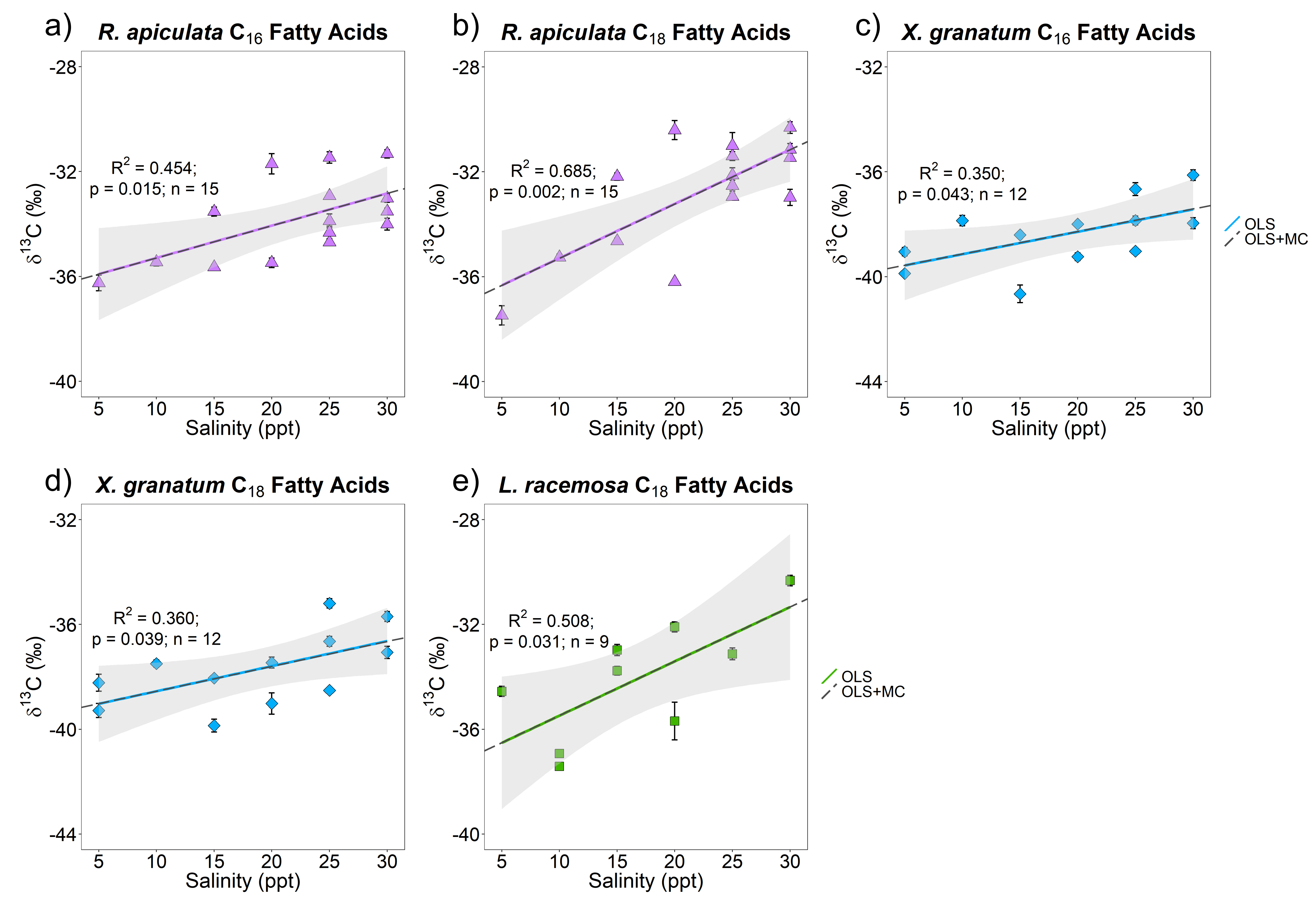

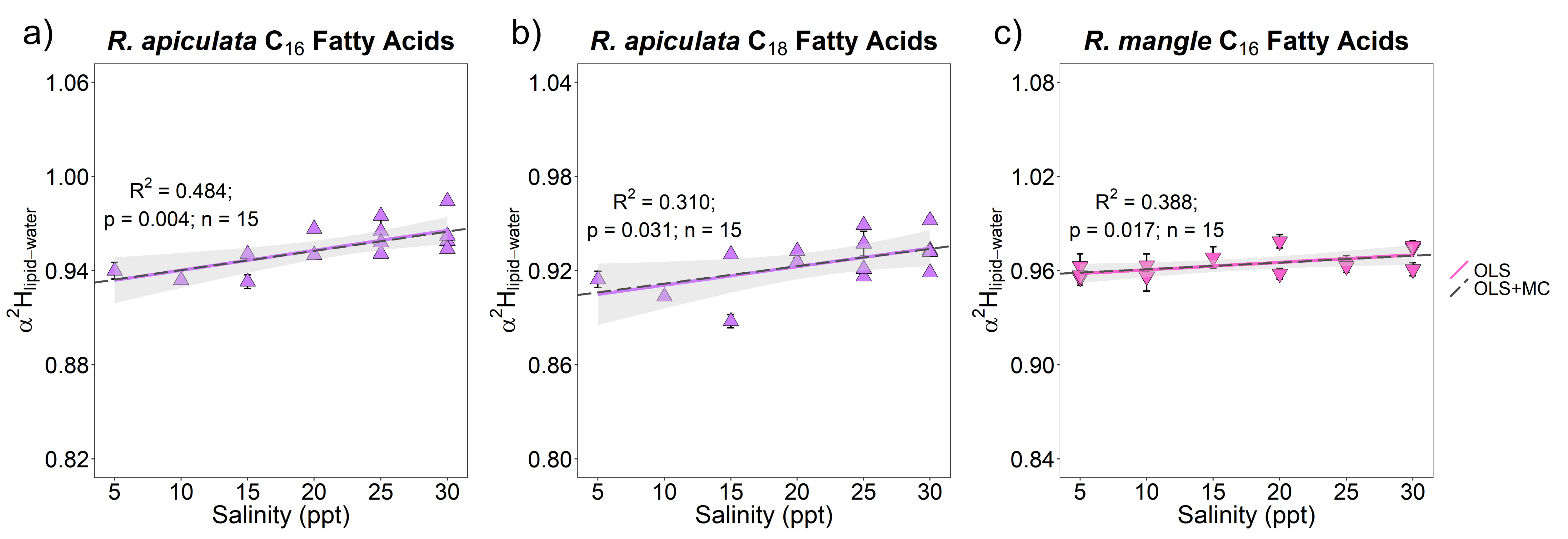
$\delta^{2} H_{\text {triterpenoids }} \varepsilon_{2016-2014}(\% \circ)$

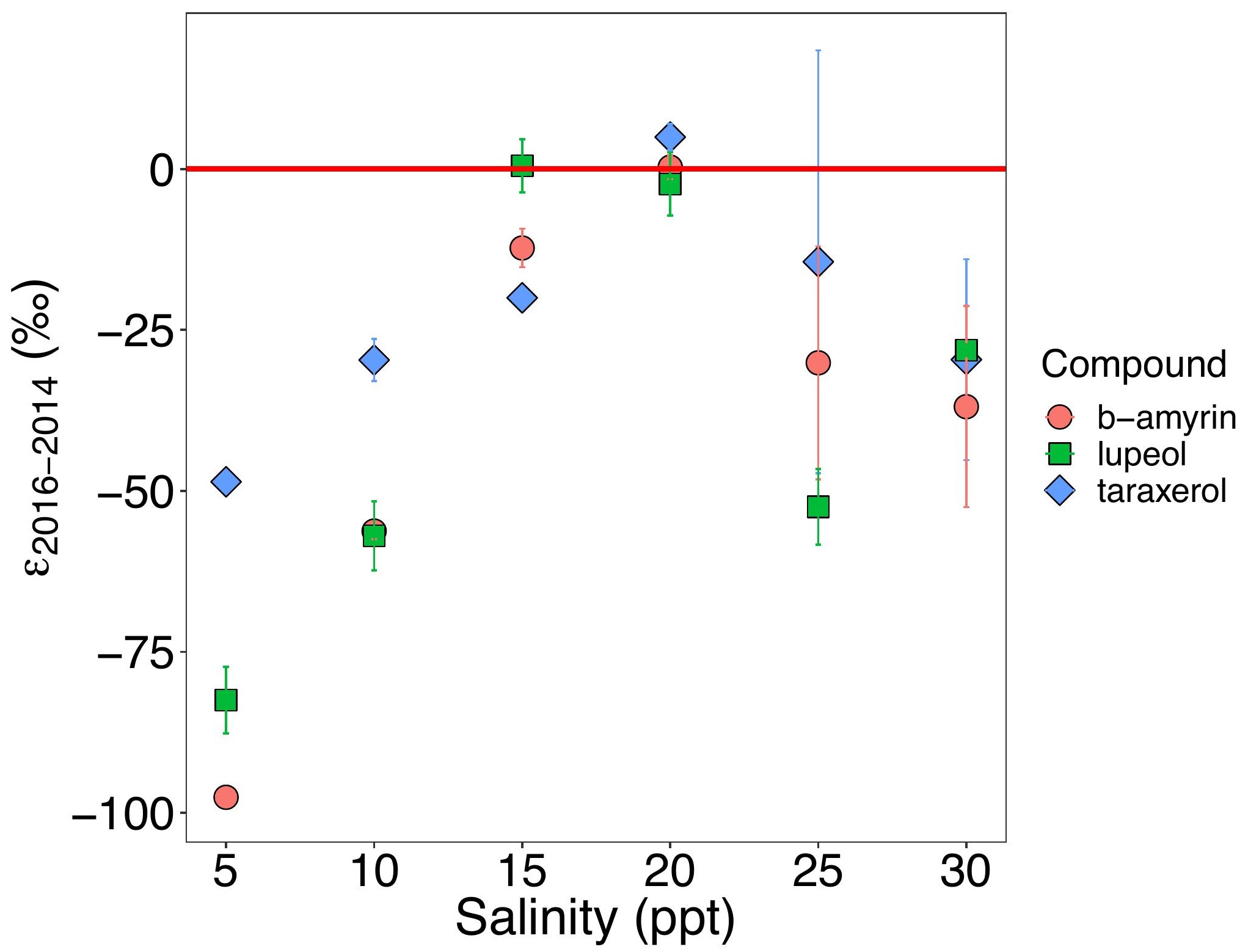

